\title{
Analysis of a landslide multi-date inventory in a complex mountain landscape: the Ubaye valley case study
}

\author{
R. Schlögel ${ }^{1, a}$, J.-P. Malet ${ }^{1}$, P. Reichenbach ${ }^{2}$, A. Remaître ${ }^{1}$, and C. Doubre ${ }^{1}$ \\ ${ }^{1}$ Institut de Physique du Globe de Strasbourg, UMR7516, Université de Strasbourg/EOST, CNRS, 5 rue René Descartes, \\ 67084 Strasbourg, CEDEX, France \\ ${ }^{2}$ CNR-IRPI, via Madonna Alta 126, 06128 Perugia, Italy \\ anow at: Institute for Applied Remote Sensing, EURAC, Viale Druso 1, 39100 Bolzano, Italy \\ Correspondence to: R. Schlögel (romy.schloegel@eurac.edu)
}

Received: 9 March 2015 - Published in Nat. Hazards Earth Syst. Sci. Discuss.: 30 March 2015

Accepted: 16 September 2015 - Published: 22 October 2015

\begin{abstract}
In the paper we analyse a multi-date landslide inventory prepared for a mountainous area affected by several landslide types with different degrees of activity, we attempt to quantify the uncertainties associated to the mapping, we measure the evolution of morphological indicators and estimate landslide activity and temporal occurrence. The inventory, covering the period 1956-2010, is prepared for the middle section of the Ubaye valley (southern French Alps) based on the analysis of multi-source documents (geomorphological maps, historical reports of landslide events, field surveys, orthophotographs and SAR (synthetic aperture radar) satellite images). The uncertainties derived from the expert interpretation of different sources of information, the landslide morphological features and the affected land covers are taken into account in relation to the source documents.

Morphological indicators are calculated to describe quantitatively the evolution of the landslides (length, area, relative elevation, runout distance). Frequency-area density functions are computed to estimate the changes in the landslide distributions and a Poisson model is used to estimate the probability of reactivation of the observed landslides and the occurrence of new failures. The proposed multi-date inventory and the associated statistics provide additional information to the event catalogue managed by the local policy makers.
\end{abstract}

\section{Introduction}

Landslide inventory maps are important documents to describe mass movement spatial distribution in a region and to prepare susceptibility, hazard and risk maps (Guzzetti et al., 2012). They are also useful to investigate the distribution, types and patterns of landslides in relation to geomorphology, lithology, land cover, tectonic settings and hydrogeological conditions (Guzzetti et al., 1996; Corominas et al., 2014; Günther et al., 2013).

Inventory maps are either archive or geomorphological inventories (Guzzetti et al., 2000; Malamud et al., 2004). Archive inventories include landslides information obtained from the literature, or other archive sources (Reichenbach et al., 1998; Salvati et al., 2003). Geomorphological landslide inventories, classified as historical, event, seasonal or multi-temporal inventories cluster different information: the movement type, the estimated age, the degree of activity, the depth, and the velocity (Guzzetti et al., 2012). Geomorphological features, such as fissures, grabens, ponds, vegetation removal and other morphological changes, may provide information on landslide activity. Geomorphological landslide inventory maps prepared for different periods associated with event landslide maps can be useful to evaluate the temporal and the spatial evolution of multiple failures over long periods of time (e.g., years to decades; Galli et al., 2008). The event-based or multi-date landslide inventories preparation is hindered by uncertainties linked to the specificity of the source documents (scale, spatial resolution, time period), the type and size of the landslides as well as by the skills of the 
expert. Preparing multi-temporal landslide inventories at regional scale requires investigating relationships among variables over different time resolutions. In these inventory maps, the date (or periods) of the landslides is attributed either on the basis of the date (or periods) of the triggers, the date of the source document (photographs, reports) or the date of field surveys (Guzzetti et al., 2012).

In this work, we propose a multi-date landslide inventory showing the evolution of landslide boundaries for more than two periods prepared from the interpretation of various types of documents. Despite modern technological advances, and the availability of new satellite products, the visual interpretation of airborne photographs is still the most common method to obtain landslide information (Guzzetti et al., 2012) though several other sources of information that may be used such as optical remote sensing images and LiDARderived topographic information (Ardizzone et al., 2007; van den Eeckhaut et al., 2007; Haneberg et al., 2009; Razak et al., 2013; Martha et al., 2010; van den Eeckhaut et al., 2012). Images acquired by synthetic aperture radar (SAR) satellite sensors are also considered as a powerful source of information, mainly for the recognition of slow-moving landslides (Singhroy and Molch, 2004; Zhao et al., 2012).

Preparing an inventory map is a time-consuming and not straightforward procedure which requires experienced geomorphologists trained in the recognition of slope features and processes (Wills and McCrink, 2002; van den Eeckhaut et al., 2005; Guzzetti et al., 2012). In addition, the quality of the final map depends on the spatial resolution of the airborne photographs, the scale of the topographic maps, and the complexity of the landscape (Carrara et al., 1992; Ardizzone et al., 2002; Galli et al., 2008). The interpretation of the airborne photographs to produce the landslide inventory map may also induce some mapping errors (Marchesini et al., 2013; Santangelo et al., 2015). According to Brardinoni et al. (2003), forest canopy (notably in old-growth forest) increases the population of "not visible" landslides which can represent up to $85 \%$ of the total number of failures. As mentioned by Bell et al. (2012), one challenge is to quantify the effect of event or continuous reactivations which leave their footprint in the landscape.

The magnitude (or intensity) of landslides depends on the landslide type and several proxies can be used for its quantification such as the landslide dimensions (area, volume, travel distance) or velocity (Corominas et al., 2014). Frequencymagnitude relationships for different locations and landslide types are frequently considered as a proxy for landslide magnitude (van den Eeckhaut et al., 2007; Florsheim and Nichols, 2013; Malamud et al., 2004; Schlögel et al., 2011; Guzzetti et al., 2006). In order to complete the quantitative analysis of the multi-date inventory, landslide temporal probability can also be assessed using a Poisson model.

The objectives of this work are the following: (i) to prepare a multi-date landslide inventory map from multi-source data, (ii) to identify and quantify uncertainties and inter- pretation errors associated to the mapping, (iii) to propose indicators to estimate the interpretation errors in order to improve the reliability of the landslide inventory maps and (iv) to analyse quantitatively the multi-date inventory. The study area is located in the middle part of the Ubaye valley (south-eastern France) severely affected by different landslides types (Maquaire et al., 2003), and the investigated time period extends from 1956 to 2010.

\section{Study area}

The Ubaye valley is located in the southern French Alps (Fig. 1a). In the middle section of the valley (e.g. the Barcelonnette Basin), several communities developed throughout the last millennia and the number of inhabitants was around 6000 people in 2012.

The Barcelonnette Basin is a geological window between two Eocene crystalline sheet thrusts (Parpaillon and $\mathrm{Au}$ tapie) overlaying autochthonous black marls (Fig. 1b). Limestone, sandstone, flysch and gypsum constitute most of the rocks within the thrusts; they constitute the steepest slopes and crests, ranging from 2500 to $3000 \mathrm{~m}$ in elevation. The slopes, with angles ranging from 5 to $45^{\circ}$, present an irregular geometry with steep convex planar and hummocky surfaces/profiles. Below the sheet thrusts, the steepest convex slopes $\left(>35^{\circ}\right)$ are carved in black marl outcrops. The gentle slopes $\left(5-15^{\circ}\right)$ correspond to moraine deposits of about 10 $20 \mathrm{~m}$ thickness which are overlaying the black marls. Scree slopes also cover large areas, especially below the sheet thrust crests with a thickness ranging from 2 to $10 \mathrm{~m}$. The lower parts of the slopes and the valley bottom are formed of torrential deposits whose thickness varies from 50 to $200 \mathrm{~m}$.

The climate is controlled by both Mediterranean and mountain influences (Malet et al., 2005a), with a clear monthly rainfall variability $(734 \pm 400 \mathrm{~mm}$ for the period 1928-2013), significant daily temperature range $\left(>20^{\circ} \mathrm{C}\right)$, more than 120 days of freezing per year (on average), long dry periods (from May to October) and the occurrence of summer rainstorms (with rainfall intensity up to $60 \mathrm{~mm} \mathrm{~h}^{-1}$ ).

Forests cover around $40 \%$ of the area, while grasslands and arable lands are present for about 25 and $5 \%$, respectively; the rest of the area (30\%) is covered by bare soils and urbanized areas.

Numerous studies were conducted for the analysis of mass movements (Flageollet et al., 1999; Malet et al., 2005a; Maquaire et al., 2003; Razak et al., 2011; Remaître et al., 2005; Thiery, 2007; Thiery et al., 2014) and several landslide types were mapped and analysed along the slopes (Fig. 1a). Typologies of slides (Cruden and Varnes, 1996) mainly constituted by rocks and debris are the following:

- shallow translational landslides (e.g. the Riou Chanal landslides, south of Uvernet; Fig. 1d); 

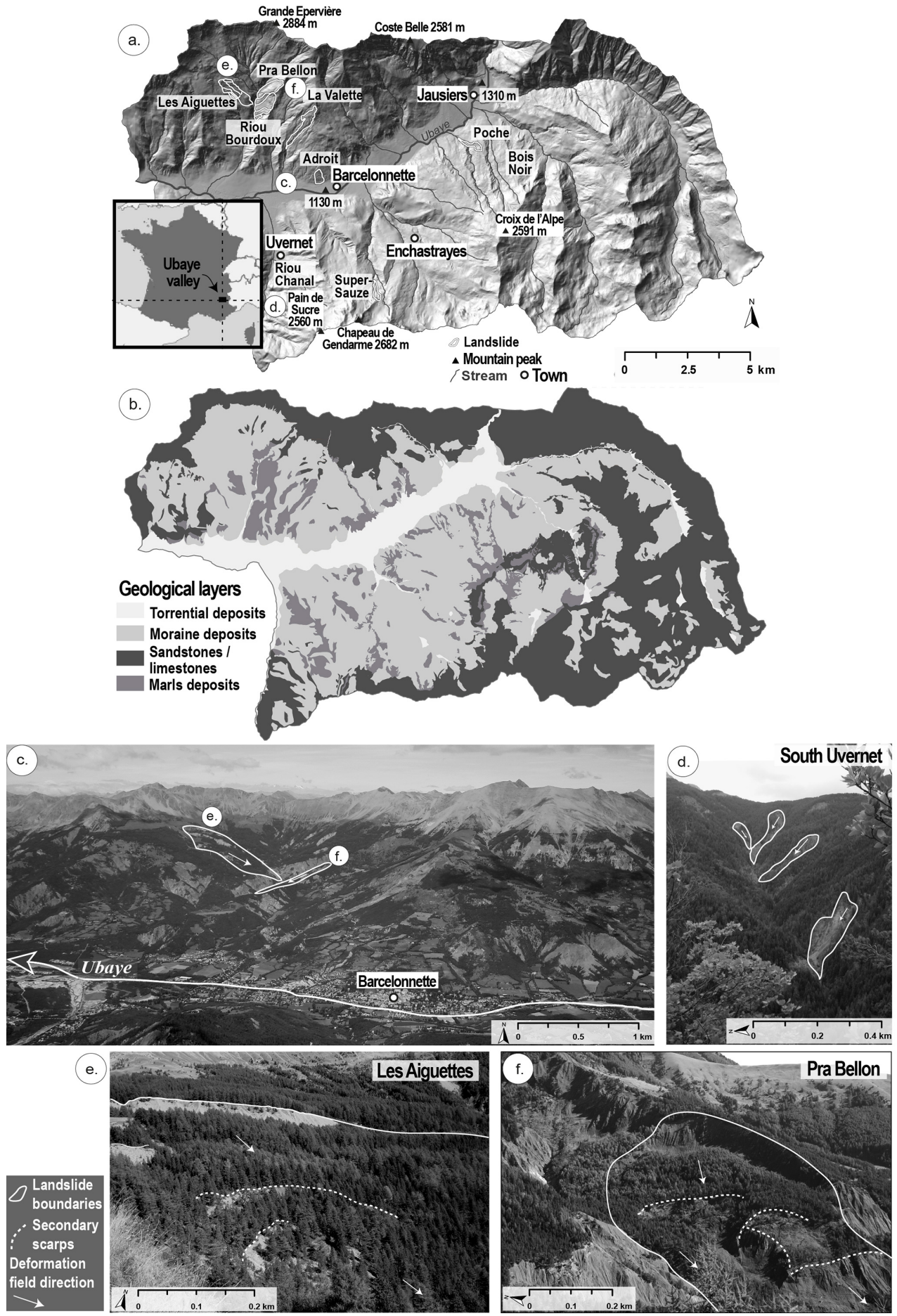

Figure 1. The Ubaye valley (southern French Alps) study area. (a) Shaded relief image of the area and location of the main monitored landslides. (b) Simplified geological map. (c) Typical landscape of the south-facing slopes located on the right riverbank of the Ubaye River. (d) Shallow translational landslides situated south of Uvernet in the Riou Chanal catchment. (e) Crown area of the Les Aiguettes deep-seated translational landslide. (f) Crown area of the Pra Bellon deep-seated rotational landslide. 
Table 1. List of the data available for the Ubaye valley used for landslide recognition and mapping.

\begin{tabular}{|c|c|c|c|c|c|c|}
\hline & Type of data & Source & Resolution & Scale & Date & Landslide information \\
\hline 1. & Orthophotograph & IGN & $1.5 \mathrm{~m}$ & $1: 35000$ & $31 / 07 / 1956$ & Location/Type \\
\hline 2. & Orthophotograph & IGN & $1.0 \mathrm{~m}$ & $1: 15000$ & $10 / 07 / 1974$ & Location/Type \\
\hline 3. & Orthophotograph & IGN & $1.0 \mathrm{~m}$ & $1: 20000$ & 01/07/1982 & Location/Type \\
\hline 4. & Orthophotograph & IGN & $0.7 \mathrm{~m}$ & $1: 25000$ & 25/07/1995 & Location/Type \\
\hline 5. & Orthophotograph & IGN & $0.5 \mathrm{~m}$ & $1: 25000$ & $24 / 06 / 2000$ & Location/Type \\
\hline 6. & Orthophotograph & IGN & $0.5 \mathrm{~m}$ & $1: 25000$ & 03/07/2004 & Location/Type \\
\hline 7. & Orthophotograph & IGN & $0.5 \mathrm{~m}$ & $1: 25000$ & $19 / 07 / 2009$ & Location/Type \\
\hline 8. & Airborne SAR DSM & IfSAR-Fugro & $5.0 \mathrm{~m}$ & - & 2009 & Location \\
\hline 9. & Elevation-line DSM & EOST $^{\mathrm{a}}$ & $10 \mathrm{~m}$ & - & 2004 & Location \\
\hline 10. & Geological map & BRGM & - & $1: 25000$ & 1974 & Location/Type \\
\hline 11. & Geomorphological map & ZERMOS & - & $1: 25000$ & 1975 & Location \\
\hline 12. & Geomorphological map & Utrecht Univ. $^{\mathrm{b}}$ & - & $1: 25000$ & 1989 & Location/Type \\
\hline 13. & Geomorphological map & $\mathrm{RTM}^{\mathrm{c}}$ & - & $1: 10000$ & 2001 & Location/Type \\
\hline 14. & Geomorphological inventory & EOST $^{\mathrm{a}}$ & - & $1: 5000$ & 2004 & Location/Time/Intensity \\
\hline 15. & Historical catalogue & RTM/BRGM & - & - & $1850-2012$ & Location/Time \\
\hline 16. & Historical reports & $\mathrm{RTM}^{\mathrm{c}}$ & - & - & 1990-2012 & Location/Time \\
\hline 17. & Dendrogeomorphic data & Irstea $^{\mathrm{d}}$ & - & $1: 3000$ & 1850-2004 & Location/Time \\
\hline 18. & L-band SAR images & EOST $^{\mathrm{e}}$ & $10 \mathrm{~m}$ & - & $2007-2010$ & Location/Time/Intensity \\
\hline
\end{tabular}

a Thiery (2007); ${ }^{\mathrm{b}}$ Salomé and Beukenkamp (1989); ${ }^{\mathrm{c}}$ Stien (2001); ${ }^{\mathrm{d}}$ Lopez-Saez et al. (2012, 2013); ${ }^{\mathrm{e}}$ Schlögel et al. (2015).

IGN: French National Geographic Institute; IfSAR-Fugro: Fugro EarthData GeoSAR airborne Interferometric Synthetic Aperture Radar; EOST: Ecole et Observatoire des Sciences de la Terre, University of Strasbourg; BRGM: Bureau de Recherches Géologiques et Minières; ZERMOS: Zones Exposées à des Risques liés aux MOuvements du Sol ; RTM: Restauration des Terrains en Montagne; Irstea: Institut national de Recherche en Sciences et Technologies pour l'Environnement et l'Agriculture.

- deep-seated translational landslides (e.g. the Aiguettes landslide, Fig. 1e; Lopez-Saez et al., 2013);

- deep-seated rotational landslides (e.g. the Pra Bellon landslide, Fig. 1f; Lopez-Saez et al., 2012);

- mudslides (e.g. the La Valette and Super-Sauze mudslides, Malet et al., 2005b; Travelletti et al., 2014).

To be consistent with the results of Thiery et al. (2007, 2014), the descriptive terms deep-seated and shallow define landslides with sliding depth of, respectively, more and less than $6 \mathrm{~m}$ (estimated from field observations).

\section{Data}

Several sources of information are available for the Ubaye valley, namely: (i) orthophotographs, (ii) hillshades and contour lines maps, (iii) geological and geomorphological maps, (iv) dendrogeomorphic data, (v) interferograms of L-band SAR images (Schlögel et al., 2015) and (vi) reports of historical landslides (Table 1).

Orthophotographs, geomorphological maps, historical catalogues and reports provide information on landslide types, locations and sometimes, activity. Seven sets of airborne orthophotographs at different scales with spatial resolution ranging from 0.5 to $1.5 \mathrm{~m}$ acquired by the French National Geographic Institute (IGN) are available for the period 19562009. Available geological and geomorphological maps provide local information on ancient and active unstable slopes.
Reports (Stien, 2001) and historical landslide catalogues are organized in a GIS point-based database as provided by the local risk managers (RTM - Restauration des Terrains en Montagne). Several people have recorded landslide events covering different portions of the territory since the $1850 \mathrm{~s}$ and the completeness of the catalogue is not guaranteed for the oldest years. Hillshade map may help for precise location of recent mass failures but hardly highlights the type of the movement. A hillshade map and contour lines were obtained automatically from an airborne SAR DSM (2009) with $5 \mathrm{~m}$ resolution, while another set of contour lines was generated manually at $10 \mathrm{~m}$ resolution from an IGN topographical map (Thiery, 2007). In addition, dendrogeomorphological data provide information on landslide activity at local scale. Data were collected for the Pra Bellon and the Bois Noir landslides (Lopez-Saez et al., 2012, 2013) and compared at the regional scale.

Since 10 years, SAR interferograms are used for landslide detection, mapping and monitoring (Canuti et al., 2004; Colesanti and Wasowski, 2006; Lu et al., 2012; Metternicht et al., 2005). For the Ubaye valley, only ascending ALOS/PALSAR images are available, limiting the coverage of the territory to $60 \%$ because of layover and slope portions hidden by the relief (Fig. 2; Cascini et al., 2009). The interpretable slope portions are oriented to the $\mathrm{N}, \mathrm{NW}, \mathrm{W}$, SW and S including all those with topographic angles lower than $10^{\circ}$. Further, according to our time series of SAR images, the ambiguity of phase measurements limits the track- 
ing to displacement rates lower than $5.9 \mathrm{~cm}$ for periods of 46 days. Interferograms obtained from SAR images were used to update geomorphological inventory, to detect features activated during recent periods and to identify unknown landslides. In this work, we use a traditional Differential Interferometric Synthetic Aperture Radar (D-InSAR) technique adapted to mountainous areas without the presence of corner reflectors. In the area, pairs of co-registered SAR images allowed to generate deformation maps helpful for the detection and mapping of ground surface changes (Hanssen, 2001). The methodology of SAR images processing with the ROI_PAC (Repeat Orbit Interferometry PACkage) and NSBAS (New Small BAseline Subsets) algorithms (Doin et al., 2011; Rosen et al., 2004) is described in Schlögel et al. (2015).

Geomorphological landslide inventories compiled for parts of the study area were organized in a GIS polygonbased database (Thiery, 2007). The inventory map provided for the year 2004 gives precise information on landslide location, type, and activity as well as some morphological indicators. As the available maps and images have different scales, spatial resolutions and formats, they were first georeferenced and orthorectified in the system NTF (New French Triangulation) Lambert zone III. Spatial extension of the main data sets used for multi-date mapping varies over the scene affecting the coverage completeness (Fig. 2).

\section{Methods}

The available maps and images were organized in a GIS according to their acquisition dates, spatial coverage (Fig. 2) and level of importance for preparing the multi-date inventory. The following sections describe the multi-steps approach used to (i) recognise and map the landslides at different periods of time, (ii) estimate the uncertainty associated to each source of information, (iii) evaluate landslide activity and (iv) analyse density maps, descriptive statistics, size-frequency distributions and temporal probability.

\subsection{The multi-date landslide inventory}

The multi-date landslide inventory was prepared at $1: 5000$ scale for the period 1956-2010 by combining 2-D visual interpretation of maps (airborne orthophotographs, hillshade maps, elevation data) and Google Earth 3-D views, analysis of geomorphological maps, processing of SAR data, consulting of reports and landslide catalogues provided by authorities and field recognition. The landslide inventory for the year 2004, published by Thiery et al. (2007), was prepared at $1: 10000$ scale through air-photo interpretation, field surveys and analysis of literature in years 2002 and 2003. After being updated and extended to a larger area at the appropriate scale according to the same mapping technique, it constituted the base document to prepare a multi-date inventory at a finer resolution. The landscape interpretation was per- formed mainly using georeferenced orthophotographs, while the geomorphological maps available for intermediate dates (1975, 1989 and 2001) were considered as ancillary data. For some landslides, historical reports were available and used to confirm the landslide evolution (Stien, 2001). An example of the maps and base inventory is presented in Fig. 3 for the Pra Bellon site, corresponding to either one large slide or multiple slides according to experts' interpretation. Qualitative comparison of different geomorphological maps (Fig. 3a-c) with the base inventory and the most recent orthophotograph (Fig. 3d) allows the interpretation of the landslide evolution over time to prepare the multi-date inventory.

Information of landslide boundaries provided by the base document was crossed and compared with the past years (i.e. $1956,1974,1982,1995,2000)$ and the recent year (2009) to detect landslides size and their shape evolutions. Orthophotographs were used to prepare the geomorphological inventories for different years, as for instance 1956 and 2009 years corresponding to $G_{56}$ and $G_{09}$, respectively. $G_{56}$ is an inventory of the landslides observed in 1956 where the relict and dormant landslides were removed; the $G_{09}$ inventory shows landslides which were (re)activated at least once in the period from 1956 to 2009, and therefore considered as active. The inventories include a qualitative estimation of the landslide changes integrated as the vegetation indicator. This indicator is able to record some landslide reactivation(s) when precise boundaries of new landslides cannot be distinguished due to the vegetation. Uncertainty of landslide interpretation depending on the ability of the expert to recognise precisely the landslides boundaries and orthophotograph quality and scale is detailed in Sect. 4.2. The relict and dormant landslides were also mapped and are shown in two different inventory maps (see definitions in Sect. 4.3). In the attribute table, each landslide polygon is coded with several descriptors (Table 2):

- landslide typology, defined according to the style of movement and/or material (shallow translational slide, deep-seated translational slide, rotational slide and mudslide);

- landslide morphology defined in terms of size (area and perimeter), elevation difference between the lowest and the highest point of the landslide body, runout distance and angle of reach (Corominas, 1996);

- landslide kinematics, defined in terms of degree of activity, average displacement rate of evaluated from the spatial evolution of the landslide boundaries, and changes of the vegetation coverage (vegetation indicator).

- landslide interpretation uncertainty index, qualifying the detectability of the landslide (re)activation by evaluating shape and activity between each date. 


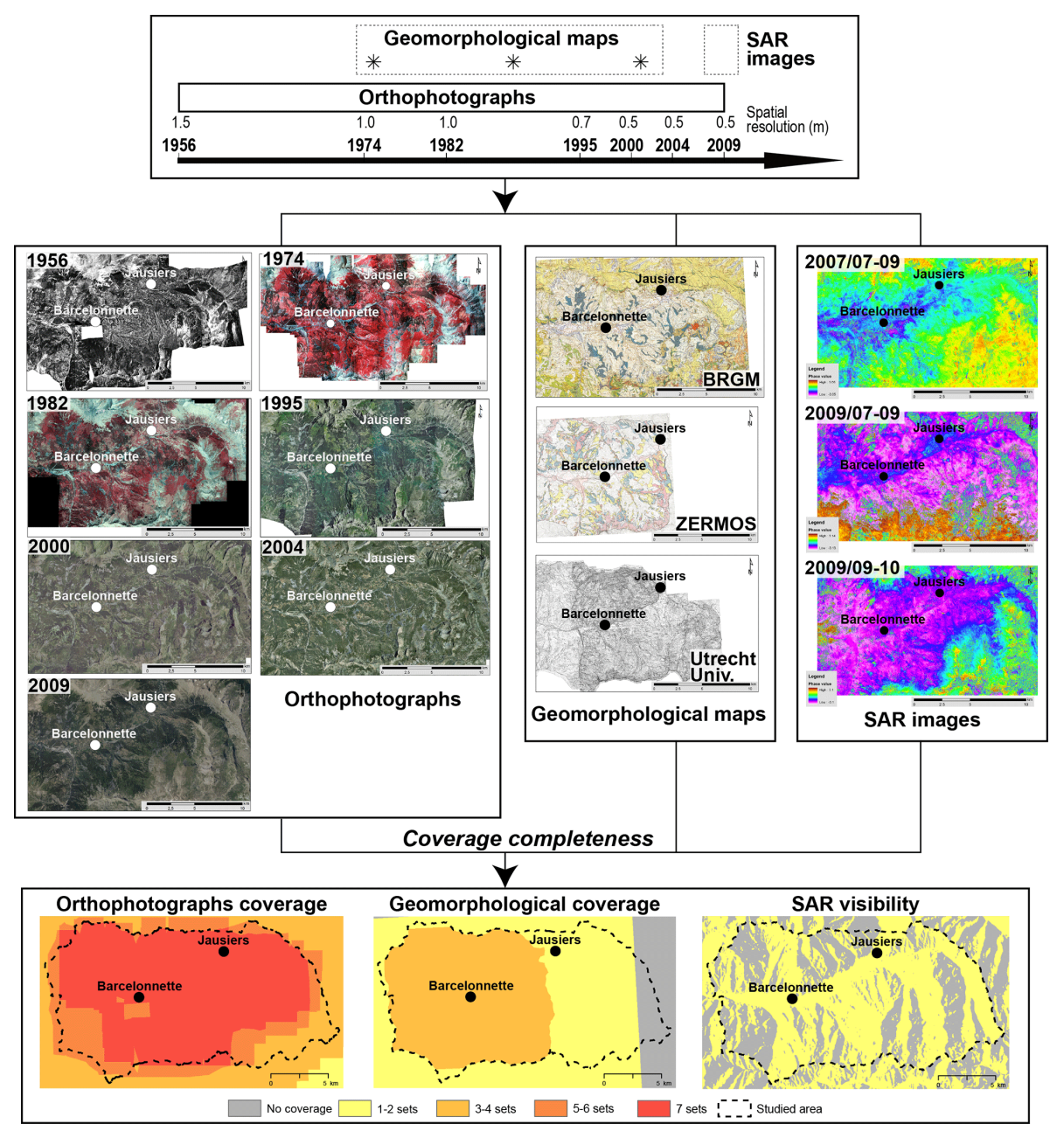

Figure 2. The figure shows available document types (orthophotographs, geomorphological maps, SAR images), their temporal coverage and spatial completeness.
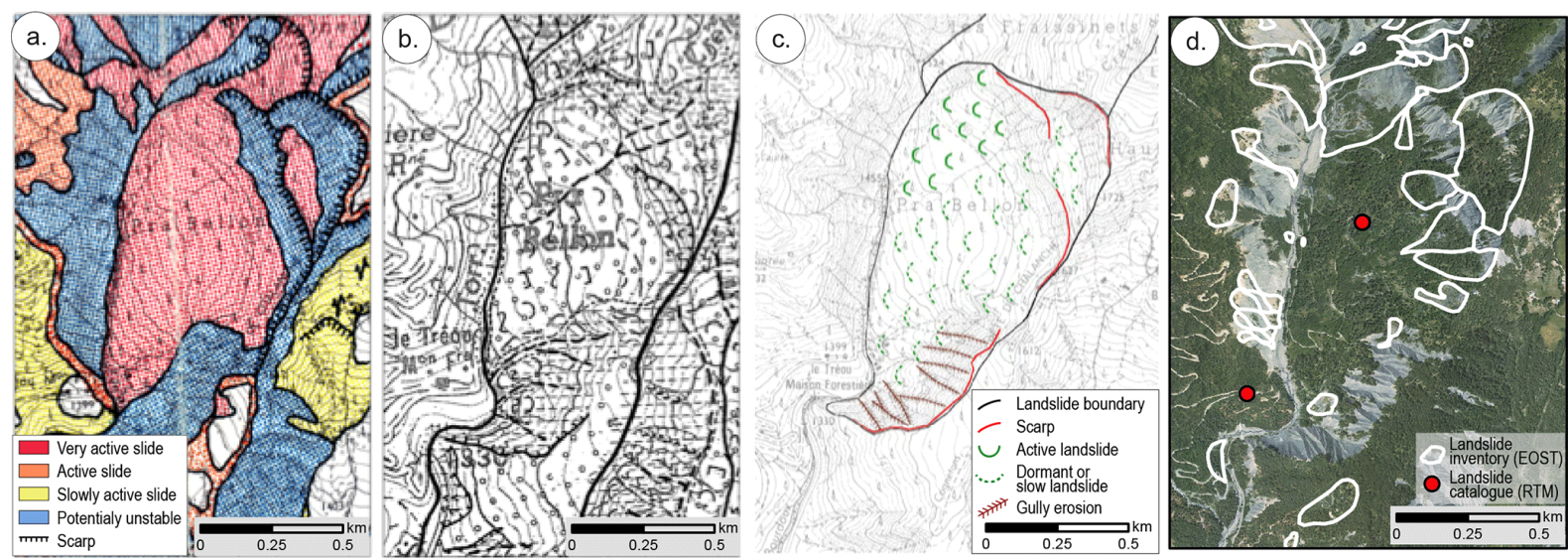

Figure 3. Different sources of information available for the Pra Bellon landslide. (a) Geomorphological map from 1975 (ZERMOS, 1975). (b) Geomorphological map from 1989 (Utrecht University; Salomé and Beukenkamp, 1989). (c) Geomorphological map from 2001 (Stien, 2001). (d) Landslide geomorphological inventory map from 2007 (Thiery, 2007). 


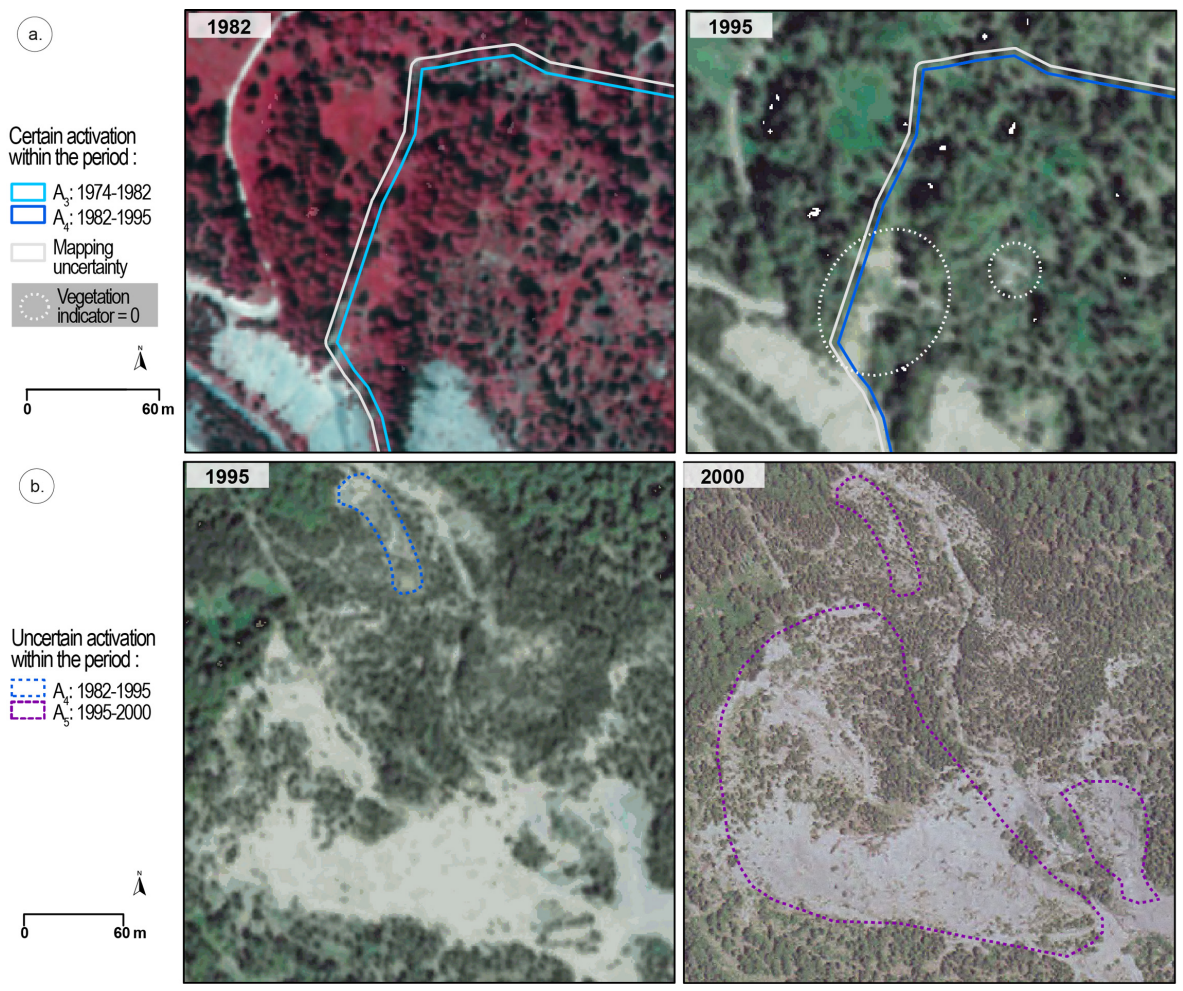

Figure 4. Examples of landslide classification according to the vegetation and uncertainty type. (a) A certain landslide reactivation with a vegetation indicator of 0 and a landslide interpretation uncertainty index of 1 . While the landslide is more than $50 \%$ under forest, the buffer areas corresponding to the quantitative mapping uncertainty extend the boundaries for 5 and $3.5 \mathrm{~m}$, respectively in 1982 and 1995 . (b) A supposed reactivation with a vegetation indicator of 0 and a landslide interpretation uncertainty index of 2 .

Information on the affected lithology, the surficial formations and the land cover of the source and deposition areas are also indicated in the attribute table.

\subsection{Uncertainty estimation}

The precision of landslide maps is defined as the ability of the expert to locate landslide features with exactness and give a good description in a GIS database, which is related to the quality of the airborne photographs and topographic maps used (Ardizzone et al., 2002). On the other hand, the accuracy is the degree to which information in the spatial database matches absolute $x-y-z$ coordinates and true attribute values, highly dependent to the orthorectification and co-registration processes (Baynes et al., 2002). Following these definitions, we identified two approaches to estimate the uncertainty: (i) the indexation of the expert skills to recognise the landslide shape and activity and (ii) the estimation of mapping uncertainty by calculating buffer zones around the landslide boundaries to consider the diversity of the data source and the vegetation cover. The landslide interpretation uncertainty index is coded into two classes (1 or 2) included in the attribute table of the geomorphological landslide inventories (Table 2). A value of 1 represents landslide (re)-activations which are clearly visible by the ex- pert (i.e. certain), while a value of 2 indicates a questionable interpretation (i.e. uncertain). This qualitative uncertainty index documents the reliability of the expert's observation and interpretation to recognise a landslide (re)-activation between two periods of time. This index also depends on the source documents (quality, spatial resolution), the landslide type (e.g. deep-seated or shallow) and the terrain conditions (e.g. forested area, grassland...). Indeed, forest harvesting, ploughed lands or new infrastructures may confuse the visual interpretation of the expert. Examples of reliable landslide reactivations and supposed ones are presented in Fig. 4a and b, respectively. Certain landslide (re)-activations with index equal to 1 are analysed statistically according to their evolution in time, while the uncertain ones indicate the visual interpretation uncertainty to detect potential reactivations.

The mapping uncertainty are coded according to two values; the percentage of forest covering the active landslide and the orthophotograph properties. This uncertainty may be related to spatial shifts between images due to the georeferencing procedure or to potential graphical mistakes. While we assume that all orthophotographs are well geocoded, the orthophotograph of 2000 provided by IGN has been wrapped to the other images but a shift of $1.5 \mathrm{~m}$ on average remains. 
Table 2. List of the attributes associated to landslide polygons stored in the database.

\begin{tabular}{|c|c|c|}
\hline Attributes & Definition & Descriptors/Units \\
\hline $\begin{array}{l}\text { Type (and sub- } \\
\text { type) }\end{array}$ & Typology of Cruden and Varnes (1996) & $\begin{array}{l}\text { Deep-seated rotational } \\
\text { slide, deep-seated } \\
\text { translational slide, shal- } \\
\text { low translational slide, } \\
\text { complex mudslide }\end{array}$ \\
\hline Degree of activity & $\begin{array}{l}\text { Definition adapted after McCalpin (1984) and } \\
\text { Varnes (1978) }\end{array}$ & relict, dormant, active \\
\hline Size & Area/perimeter & $\mathrm{m}^{2} / \mathrm{m}$ \\
\hline Elevation range & $\begin{array}{l}\text { Difference between the highest and the lowest elevation } \\
\text { points measured along the slide perimeter }\end{array}$ & $\mathrm{m}$ \\
\hline $\begin{array}{l}\text { Longest distance } \\
\text { (runout) }\end{array}$ & $\begin{array}{l}\text { Horizontal distance between the highest and lowest } \\
\text { points located along the slide perimeter }\end{array}$ & $\mathrm{m}$ \\
\hline Angle of reach & Angle of the line joining the scarp and the landslide toe & $\circ$ \\
\hline $\begin{array}{l}\text { Average displace- } \\
\text { ment rate }\end{array}$ & $\begin{array}{l}\text { Landslide evolution calculated from the spatial evolu- } \\
\text { tion of its spatial boundaries over time }\end{array}$ & $\mathrm{m} \mathrm{yr}^{-1}$ \\
\hline $\begin{array}{l}\text { Vegetation indica- } \\
\text { tor }\end{array}$ & Qualitative estimation of the degree of activity & $\begin{array}{l}0 \text { (reactivation) } 1 \text { (no } \\
\text { change) }\end{array}$ \\
\hline $\begin{array}{l}\text { Landslide interpre- } \\
\text { tation uncertainty } \\
\text { index }\end{array}$ & Estimation of the visual interpretation & 1 (certain) 2 (uncertain) \\
\hline
\end{tabular}

This shift has been estimated by comparing ground control points over the whole area. Therefore, in this uncertainty factor, we consider the mapping errors by computing a buffer area corresponding to the spatial shift, or if none is observed, to the spatial resolution associated to the orthophotograph. In optimal conditions, meaning good detectability of the whole landslide body (with no or a few forest coverage), we assume that the landslide boundaries can be mapped with an uncertainty corresponding to the spatial resolution. The whole set of orthophotographs is of good quality with scales varying between $1: 15000$ and $1: 35000$. We assume minimal mapping uncertainties corresponding to an area extended of 1.5, $1.0,1.0,0.7,1.5,0.5$ and $0.5 \mathrm{~m}$ for 1956, 1974, 1982, 1995, 2000, 2004 and 2009, respectively around the original digitized features. For the geomorphological inventories of 2009, SAR images are used as complement of information for the landslide mapping. The SAR images have a spatial resolution of $10 \mathrm{~m}$ and deformation field measured by D-InSAR is around $1 \mathrm{~cm}$ (Schlögel et al., 2015). In this quantitative mapping uncertainty, we only consider the orthophotograph properties to calculate the uncertainty associated to the data source. This uncertainty type can vary depending on the difficulties to recognize landslide boundaries under forest. To consider the latter in the uncertainty mapping, we propose to extend the buffer area if the landslide is covered by more than $50 \%$ of forest. Thus, the buffer area of landslide boundaries is the value corresponding to the data resolution (or shift) if the landslide is covered by less than $50 \%$ of forest, while it is the data resolution multiplied by a factor of 5 if the landslide is more than $50 \%$ under forest (see Fig. 4a). These thresholds correspond in the first case to the Nyquist-Shannon sampling theorem stating that an object is perfectly detected on pixelbased images when its size is twice the resolution of the data (Shannon, 1949). Detailed information on the underestimation of the landslide areas and the uncertainty of the boundary location under forest cover are not clearly available in the literature (Wolfe and Williams, 1987). In the case of dense forest coverage, based on several test cases in our data set, we assume that the width of tree's canopy generates an uncertainty on the detection of the underlying features which is approximately equal to five times the resolution. Consequently, the width of the buffer is 7.5, 5.0, 5.0, 3.5, 2.5, 2.5 and $2.5 \mathrm{~m}$ for 1956, 1974, 1982, 1995, 2000, 2004 and 2009, respectively. For the second uncertainty indicator, we assume that this buffer area corresponds to minimal but relevant extended landslide boundaries. Therefore, we consider that the mostly extended buffer indicates a mapping uncertainty of $7.5 \mathrm{~m}$ when the boundaries are not clearly identified. To sum up, the buffer area (i.e. the uncertainty mapping) varies between 0.5 to $1.5 \mathrm{~m}$ if the forest coverage is below $50 \%$, while it varies between 2.5 to $7.5 \mathrm{~m}$ if more than half of the landslide is under forest. Example of reliable landslide reactiva- 
tions (uncertainty index of 1) with their associated quantitative mapping uncertainty are presented in Fig. 4a for the period 1974-1982 and 1982-1995 with buffer zone of 5 and $3.5 \mathrm{~m}$, respectively.

\subsection{Landslide activity}

The degree of activity of the landslides was evaluated and classified in three categories using the terminology proposed by McCalpin (1984): (i) relict when the landslide which occurred 10000 years BP is still visible in the landscape but does not show morphological evidences of deformation (oldest and largest failures dated from the Holocene period; Jorda, 1980); (ii) dormant when slope evidence of landslide movement can be estimated for a period of 100-10 000 years, and (iii) active when the displacement rates are in the range of few centimetres per year or when significant changes of the sub-surface morphology are observed during the last 100 years. In this study, the active landslides consist in slope movements represented either by a change in landslide size (retrogression of the main scarp, enlargement, downhill progression of the material) or by internal deformation (development of secondary scarps and lobes, changes in the soil surface state) between 1956 and 2009.

The inventories of active landslides $\left(A_{1}\right.$ to $\left.A_{7}\right)$ are prepared with the visual orthophotos interpretation, evaluating the landslide differences observed for the studied intervals (Fig. 5a). The $A_{1}$ inventory provides information on landslides pre-1956; the $A_{2}, A_{3}, A_{4}, A_{5}, A_{6}$ and $A_{7}$ inventories provide information on the new and reactivated landslides, respectively for the period between 1956 and 1974, between 1974 and 1982, between 1982 and 1995, between 1995 and 2000, between 2000 and 2004 and between 2004 and 2009.

The analysis of nine L-band SAR interferograms covering the period 2007-2010 is used to complement the database on the recent landslide activity. The boundaries of the landslides detected by SAR interferograms were adjusted according to the morphology of the slope and the interpretation of the orthophotographs (Fig. 5b). Specific spatial arrangements of wrapped phase values (e.g. decametric to hectometric circular footprints with a continuous value change higher than a phase difference of $\pm 0.9 \mathrm{rad} \mathrm{period}^{-1}$ or $0.02 \mathrm{~cm} \mathrm{day}^{-1}$; Schlögel et al., 2015) are considered as landslide signals. For slow-moving landslides, fringes can be determined in these footprints (Fig. 5b) and displacement rates are estimated (Fig. 5c). For fast-moving landslides, displacement rates cannot be estimated and only the presence of a deforming slope is determined on the basis of speckles looking like noise (see Fig. 5b with the example of the landslide located at the NE).

In 2012, field surveys aiming to verify the InSAR signals concluded that 110 signals corresponded to landslide events (Fig. 6b) and were integrated in the $G_{09}$ geomorphological inventory and in the $A_{7}$ inventory (Fig. 6a). The other 230 verified InSAR signals were not considered as landslide events as they corresponded either to changes in the soil surface properties (new infrastructures, cultivated crops or harvested forests) or to other types of ground deformation (such as rockfall, sackung and gully erosion).

\subsection{Statistical analyses of the landslide inventory maps}

Several statistical indicators are calculated to evaluate the density, mobility and size evolution, size-frequency distributions and return periods to calculate temporal probability of landslide events.

\subsection{Landslide density maps}

Landslide density maps are prepared to quantify the spatial abundance of landslides (Campbell, 1973; DeGraff and Canuti, 1988; Wright et al., 1974). Landslide density is the proportion of landslide surfaces per mapping units and is computed with Eq. 1:

$D_{\mathrm{L}}=\frac{A_{\mathrm{L}}}{A_{\mathrm{M}}}, 0 \leq D_{\mathrm{L}} \leq 1$,

where $A_{\mathrm{M}}$ is the area of the mapping unit and $A_{\mathrm{L}}$ is the landslide cumulated surface in the mapping unit. Density is calculated by counting the slope portion affected by active and new landslides for the period 1956-2009. In our case, the analysis is performed using a $250 \mathrm{~m}$ grid (corresponding to an area of $62500 \mathrm{~m}^{2}$ ). The threshold used to consider a landslide grid cell is the presence of a landslide for a surface larger than $250 \mathrm{~m}^{2}$ (e.g $\left.0.04 \%\right)$. The landslide density is classified into four classes: [0-0.3[; [0.3-0.5[; [0.5-0.7[; [0.7$1.0]$. The $2009\left(G_{09}\right)$ geomorphological inventory is used to prepare the density maps. Criteria were chosen according to the high variability of the landslide sizes in this area: mean landslide area around $27000 \mathrm{~m}^{2}$ with standard deviation of ca. $80000 \mathrm{~m}^{2}$ ).

\subsubsection{Landslide mobility and evolution}

Descriptive statistics on landslide mobility and activity evolution are calculated combining the different geomorphological inventories $\left(R, D, G_{56}\right.$ and $G_{09}$; Table 3$)$. The age of relict $(R)$ and dormant $(D)$ landslides is unknown and no reactivation of these landslides has been recorded over the last 60 years. For the active landslides over the last 60 years, the evolution of morphological descriptors used as proxies of landslide mobility between 1956 and 2009 is presented for the inventories $G_{56}$ and $G_{09}$. For the $G_{56}$ inventory, landslide features are well distinguished but the date of the triggering event is unknown. However, we decided to only keep landslides showing an indication of activity at least one time between 1956 and 2009 in this geomorphological inventory. For the $G_{09}$ inventory, both the new and reactivated landslides between 1956 and 2009 are considered (Table 3). A landslide activation corresponds either to an internal morphological change within the landslide boundary, or an en- 


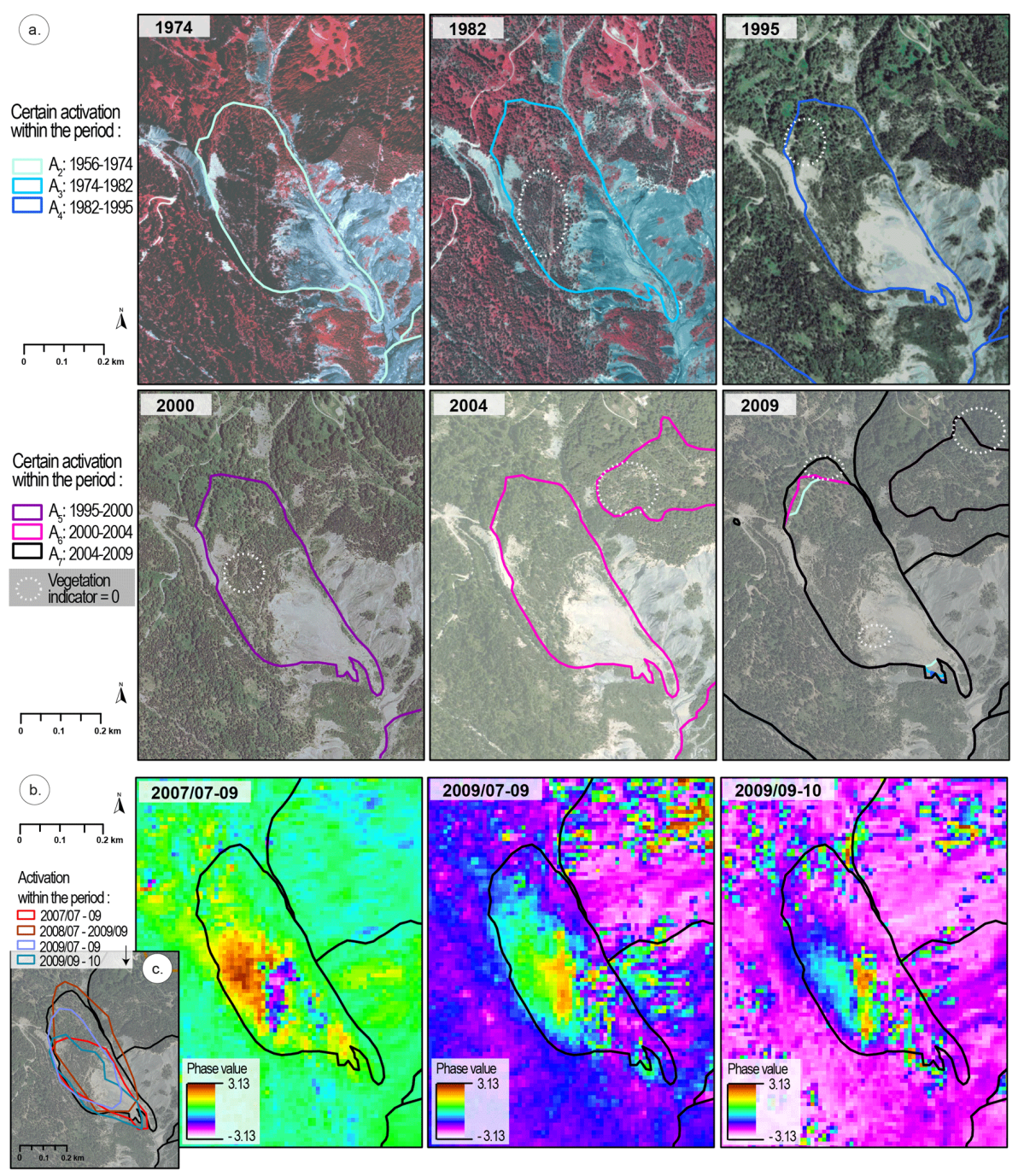

Figure 5. Combination of orthophotographs and SAR interferograms for the creation of the landslide geomorphological inventories. (a) Extension of active landslides in 1974, 1982, 1995, 2000, 2004, 2009 on the orthophotograph on a slope located in the Riou Bourdoux catchment. (b) SAR interferograms of the same slope with several landslide signals corresponding to specific spatial arrangement of phase values (in radians) for three periods of 46 days (July-September 2007, July-September 2009, and September-October 2009). The extension of the landslides interpreted by visual interpretation of the series of orthophotographs and from field recognitions is indicated with the black line. Sub-units within the landslides of various surface displacement rates are identified. (c) Interpreted extension of the landslide sub-units from the SAR interferograms for three time periods of 46 days.

largement of the landslide size (Fig. 5a). The average number of landslides and areas in the study area per year is listed in Table 4. Comparison of $G_{09}$ and $G_{56}$ allows us to estimate the size evolution and the mobility of active landslides in comparison to $R$ and $D$ landslides. The angle of reach (as a proxy of landslide mobility) is calculated for different landslide types mapped in $G_{09}$.

\subsubsection{Landslide size-frequency distributions}

Landslide area-frequency distributions are calculated to compare the landslide distributions for several time periods and morphological sub-units. Two size distribution models were proposed in the literature: (1) the Double Pareto distribution (Stark and Hovius, 2001) defined by a positive and a negative power scaling, and (2) the Inverse Gamma distribution (Malamud et al., 2004) defined by a power-law decay for medium and large landslides and an exponential rollover for small landslides. According to best-fit criteria on our data, we choose a maximum-likelihood fit of the simplified version of the double Pareto (DPS) distribution defined by Eq. (2):

$$
\operatorname{pdf}(x \mid \alpha, \beta, t)=\frac{\beta(t / \alpha)}{\left(1+(x / t)^{-\alpha}\right)^{(1+(\beta / \alpha))}\left(x^{(\alpha+1)}\right)},
$$

where $\alpha$ controls the slope of the distribution for high values tail, $\beta$ controls the slope for low values, and $t$ con- 

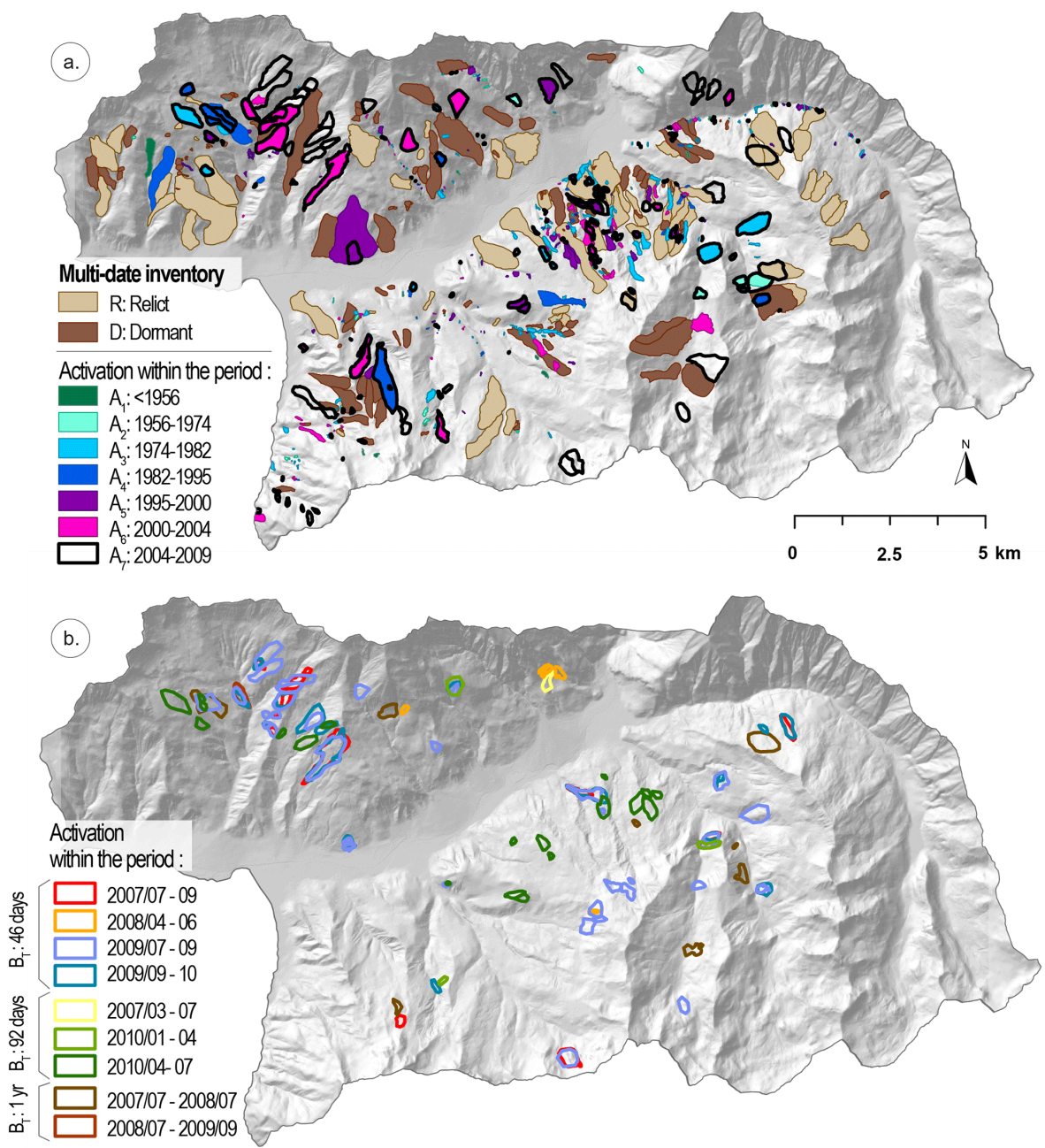

Figure 6. Multi-date landslide geomorphological inventory maps. (a) In the map landslides are classified according to the degree of activity ( $R$ : relict; $D$ : dormant; $A_{1}-A_{7}$ : active). (b) Map showing landslide activations for the period 2007-2010 detected by D-InSAR with different temporal baselines $\left(B_{\mathrm{T}}=46\right.$ days, 92 days and 1 year).

Table 3. Descriptive statistics of the geomorphological inventories for different landslide types and degrees of activity. Inventories are divided according to the degree of activity: $R$ (relict, i.e. inactive landslides), $D$ (dormant, i.e. inactive-mature landslides), $G_{56}$ (landslide triggered before 1956 and still active between 1956 and 2009) and $G_{09}$ (active and new landslides from 1956 to 2009). The abbreviations "rot." and "transl." stand for "rotational" and "translational", respectively.

\begin{tabular}{lllllll}
\hline & Date & Type & Activity & Number & Area $\left(\mathrm{km}^{2}\right)$ & Density \\
\hline$R$ & Very old & Deep-seated rot./transl. & Relict & 59 & 16.7 & $7.1 \%$ \\
$D$ & Old & Deep-seated rot./transl. & Dormant & 115 & 11.5 & $4.9 \%$ \\
$G_{56}$ & $\leq 1956$ & all & New, active & 512 & 13.7 & $5.8 \%$ \\
& & Deep-seated rot. & New, active & 174 & 9.3 & $3.9 \%$ \\
& & Deep-seated transl. & New, active & 287 & 4.1 & $1.7 \%$ \\
& & Shallow transl. & New, active & 46 & 0.2 & $0.1 \%$ \\
$G_{09} \leq 2009$ & Mudslide & New, active & 5 & 0.2 & $0.1 \%$ \\
& all & New, active & 614 & 16.6 & $7.1 \%$ \\
& Deep-seated rot. & New, active & 208 & 10.7 & $4.5 \%$ \\
& Deep-seated transl. & New, active & 345 & 4.9 & $2.1 \%$ \\
& Shallow transl. & New, active & 55 & 0.4 & $0.2 \%$ \\
& Mudslide & New, active & 6 & 0.7 & $0.3 \%$ \\
\hline
\end{tabular}


Table 4. Number and size of new and active landslides for different time periods: $A_{1}$ (before 1956), $A_{2}$ (from 1956 to 1974 ), $A_{3}$ (from 1974 to 1982), $A_{4}$ (from 1982 to 1995), $A_{5}$ (from 1995 to 2000), $A_{6}$ (from 2000 to 2004) and $A_{7}$ (from 2004 to 2009 ).

\begin{tabular}{lllllll}
\hline & Date & Activity & Number & Number yr $^{-1}$ & Area yr $^{-1}$ & Density \\
\hline$A_{1}$ & $(*) \leq 1956$ & Active & 74 & - & - & - \\
$A_{2}$ & 1956 [to 1974] & Active & 131 & 7.3 & $1.8 \times 5$ & $1.4 \%$ \\
& & New & 28 & 1.6 & $1.9 \times 4$ & $0.1 \%$ \\
$A_{3}$ & \multirow{2}{*}{1974 [to 1982] } & Active & 265 & 33.1 & $7.9 \times 5$ & $2.7 \%$ \\
& & New & 35 & 4.4 & $2.0 \times 4$ & $0.1 \%$ \\
$A_{4}$ & \multirow{2}{*}{1982 [to 1995] } & Active & 148 & 11.4 & $4.3 \times 5$ & $2.4 \%$ \\
& & New & 13 & 1.0 & $4.8 \times 3$ & $0.1 \%$ \\
$A_{5}$ & \multirow{2}{*}{1995 [to 2000] } & Active & 103 & 20.6 & $8.0 \times 5$ & $1.7 \%$ \\
& & New & 13 & 2.6 & $4.3 \times 4$ & $0.1 \%$ \\
$A_{6}$ & \multirow{2}{*}{2000 [to 2004] } & Active & 111 & 27.8 & $9.4 \times 5$ & $1.6 \%$ \\
& & New & 4 & 1.0 & $8.3 \times{ }^{3}$ & $0.1 \%$ \\
$A_{7}$ & \multirow{2}{*}{2004 [to 2009] } & Active & 116 & 23.2 & $1.4 \times 6$ & $3.0 \%$ \\
& & New & 11 & 2.2 & $1.6 \times 5$ & $0.3 \%$ \\
\hline
\end{tabular}

${ }^{(*)}$ : the precise date is unknown.

trols the maximum position of the distribution function (rollover). The web tool developed by Rossi et al. (2012) was used to estimate the DPS distributions of the landslide area directly from the landslide inventory maps. Different frequency density functions were calculated considering the lithology of the landslide source areas (marls, moraine, limestones/sandstones/screes), two morphological sub-units (northern zone, southern zone combined with eastern zone in order to take into account enough landslides in the statistical analysis) and the degree of activity ( $D, G_{56}$ and $G_{09}$, respectively in Table 3). These partitions were constituted in order to count enough elements per data set to compare.

\subsubsection{Landslide temporal probability}

The Poisson distribution is a discrete distribution function used for characterizing the temporal occurrence of landslides. The probability of experiencing $n$ landslides during time $t$ is calculated with Eq. (3):

$$
P\left[N_{\mathrm{L}}(t)=n\right]=P_{t}=e^{(-\lambda t)} \frac{(\lambda t)^{n}}{n !} \quad \text { with } n=0,1,2 \ldots,
$$

where $\lambda$ is the estimated average rate of landslide occurrence, which corresponds to $1 / \mu$, with $\mu$ the estimated mean recurrence interval between successive failure events. The model parameters $\lambda$ and $\mu$ are usually obtained from a historical catalogue of landslide events or from a multi-date landslide inventory map. In our multi-date inventory, $\lambda$ corresponds to the number of landslides recorded in the study area divided by the period considered (e.g. 10 landslides in 53 years $=0.189$ landslides $\mathrm{yr}^{-1}$ ), while $\mu$ is the mean time between two successive landslides (53 years with 10 landslides $=5.3$ years). A simple approach is therefore used to estimate the temporal probability of landslide reactivation by calculating how many times a portion of the territory is affected by landslides for a given period of time. The exceedance probability of having one or more landslides in each grid-cell $(250 \times 250 \mathrm{~m})$ is computed by (i) ascertaining the mean recurrence interval of landslides in each mapping unit (from 1956 to 2009), (ii) assuming that the rate of slope failures remains the same for the future, and (iii) using a Poisson probability model (Crovelli, 2000; Guzzetti et al., 2003, 2005). The landslide recurrence is calculated per grid-cell on the basis of the observed rate of landslide occurrence for the period 1956-2009, knowing the interval of (re)-activations (e.g. $A_{2}, A_{3}, A_{4}, A_{5}, A_{6}$ and $A_{7}$ ).

\section{Results}

\subsection{Analysis of landslide density}

In this section we compare the location and extension of slope failures reported in the geomorphological inventory of active landslides observed in $2009\left(G_{09}\right)$ with the 1956 geomorphological inventory $\left(G_{56}\right)$ (Table 3$)$.

The density of active landslides in Ubaye is ca. 2.6 landslides $\mathrm{km}^{-2}$ (for a total area of $235 \mathrm{~km}^{2}$ ). The density of deep-seated rotational and deep-seated/shallow translational slides (Table 3) affecting the test area is computed using a grid cell of $250 \mathrm{~m} \times 250 \mathrm{~m}$ (Fig. 7a, b). The density is computed for three different morphological units (Fig. 7) delimited by the E/W-oriented Ubaye River (northern and southern areas, zone 1 and zone 2, respectively) and by the "Montagne de l'Alpe" passing by the "Croix de l'Alpe" crest N/S-oriented (eastern area or zone 3). High density of translational slides is observed in zone 2 where they are distributed homogeneously (Fig. 7a and b), while they are more concentrated in the north of zone 3. Their average size is $20755 \mathrm{~m}^{2}$ in zone 1 ( 3 landslides $\mathrm{km}^{-2}$ ), 


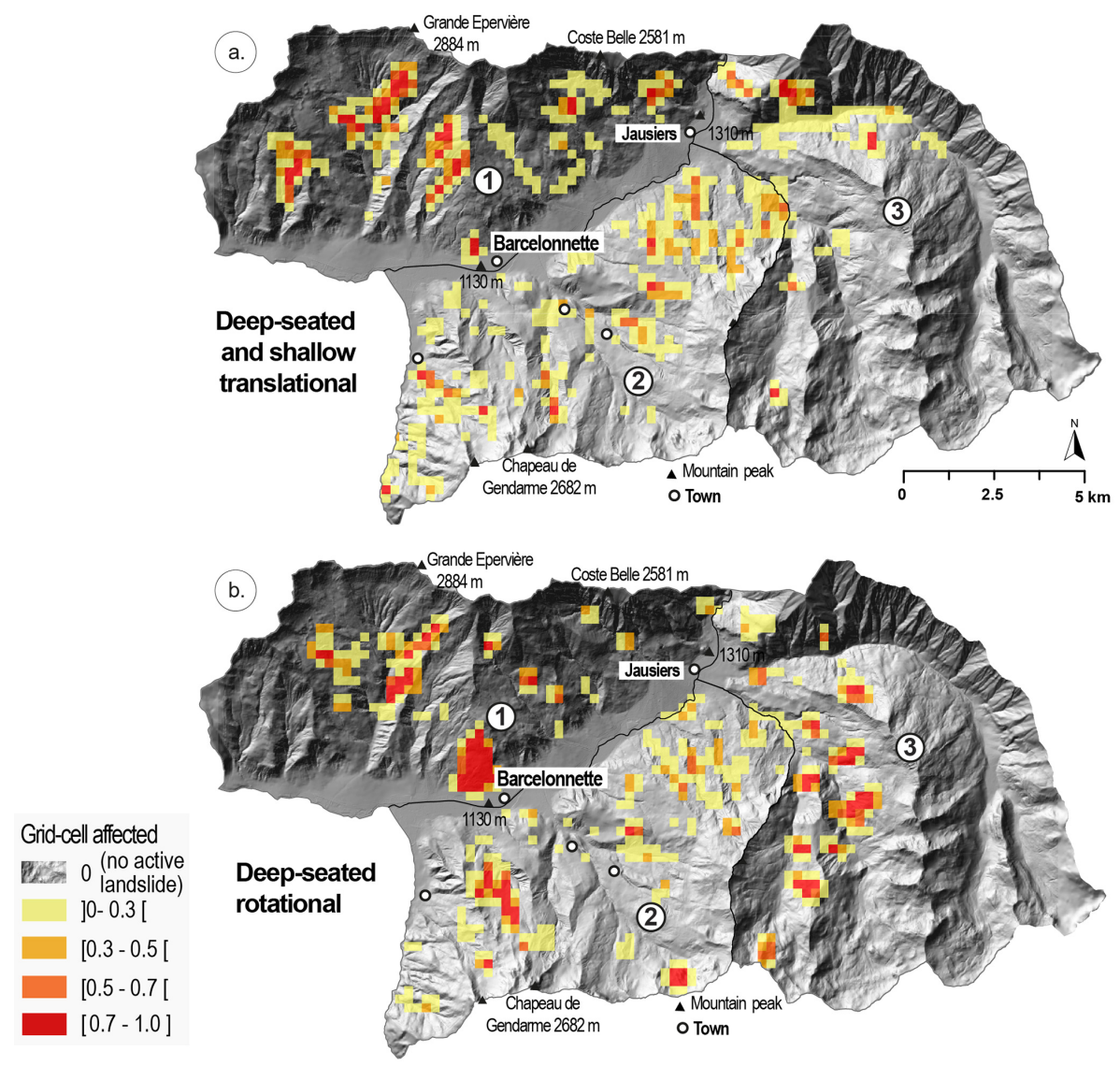

Figure 7. Landslide density maps. (a) Percentage of grid-cell affected by active deep-seated and shallow translational slides. (b) Percentage of grid-cell affected by active deep-seated rotational slides. The grid-cell dimension is $250 \mathrm{~m} \times 250 \mathrm{~m}$.

$12855 \mathrm{~m}^{2}$ in zone $2\left(1.6\right.$ landslides $\mathrm{km}^{-2}$ ) and $10975 \mathrm{~m}^{2}$ in zone 3 ( 0.9 landslides $\mathrm{km}^{-2}$ ). Deep-seated rotational slides are less present in zone 1 and rarely observed to the east of the Riou Versant (Fig. 7b). Their average size is $85700 \mathrm{~m}^{2}$ in zone 1 (0.6 landslides $\left.\mathrm{km}^{-2}\right), 25420 \mathrm{~m}^{2}$ in zone $2\left(1.8\right.$ landslides $\left.\mathrm{km}^{-2}\right)$, and $109500 \mathrm{~m}^{2}$ in zone 3 $\left(0.3\right.$ landslides $\left.\mathrm{km}^{-2}\right)$. In zone 3 , the landslide average area is almost 10 times larger for rotational slides than for translational slides. The slopes oriented to the west are more affected by landslides (i.e. mean slope orientations of 220 and $226^{\circ}$; Figs. $7 \mathrm{a}, \mathrm{b}$ and $8 \mathrm{a}$ ). The average value of the mean landslide slope angles reaches $25^{\circ}$ with a standard deviation of $4^{\circ}$. The deep-seated landslides and the three complex mudslides have been mostly reactivated in regolith deposits (i.e. moraine and weathered marls) constituting most of the territory. The few shallow translational landslides are almost equally observed in bedrocks and regolith deposits.

Figure 8a indicates that slopes oriented to the N, NW and $\mathrm{W}$ are mostly affected by active landslides. This observation might be explained by a longer persistence of snow cover on these slopes in winter and early spring but the inventory completeness is also influenced by the SAR coverage. In addi- tion, slopes oriented to the NW and $\mathrm{W}$ are more represented over the area, while it is the opposite for those oriented to the NE. Percentage of forested area is also higher to the NW and lower to the NE and E. Correlation between the landslide occurrences and the land cover highlights that around $65 \%$ of the active landslides are more than $50 \%$ under forest.

\subsection{Analysis of landslide mobility and evolution}

This section describes the landslide geometrical parameters for relict, dormant and active landslides $(R, D$, and $G_{09}$; Table 3) in terms of mobility as well as spatial and temporal evolution. According to the complete landslide inventory $\left(R, D\right.$, and $\left.G_{09}\right)$, the area is affected by 788 mass movements corresponding to an average density of ca. 3.4 landslides $\mathrm{km}^{-2}$. 59 slides are relict, 115 are dormant and 614 slides are classified as active (i.e. 2.6 landslides $\mathrm{km}^{-2}$ ). In terms of affected surfaces, the relict, dormant and active slides correspond respectively to $7.1 \%$, $5.8 \%$ and $7.1 \%$ of the surface of the area (Table 3). The dormant landslides are less represented in surface but more numerous than the relict landslides (Fig. 8b). The active landslides (more than three-quarters of the total number of 


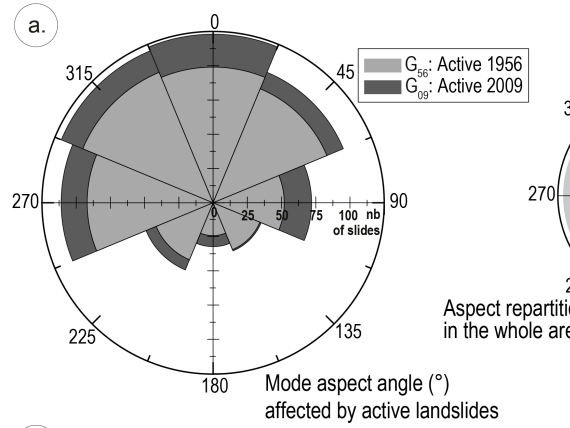

c.

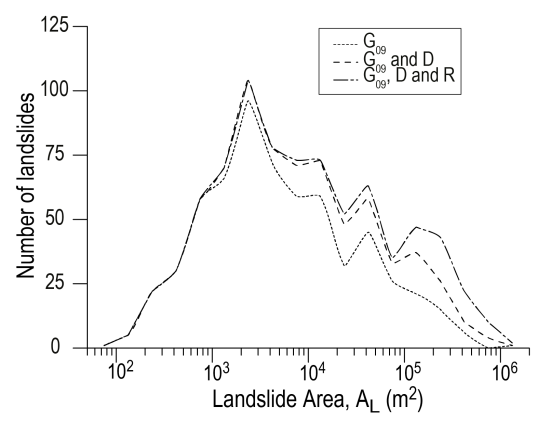

b.

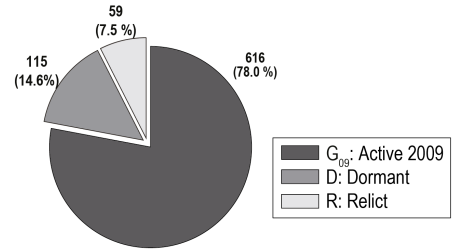

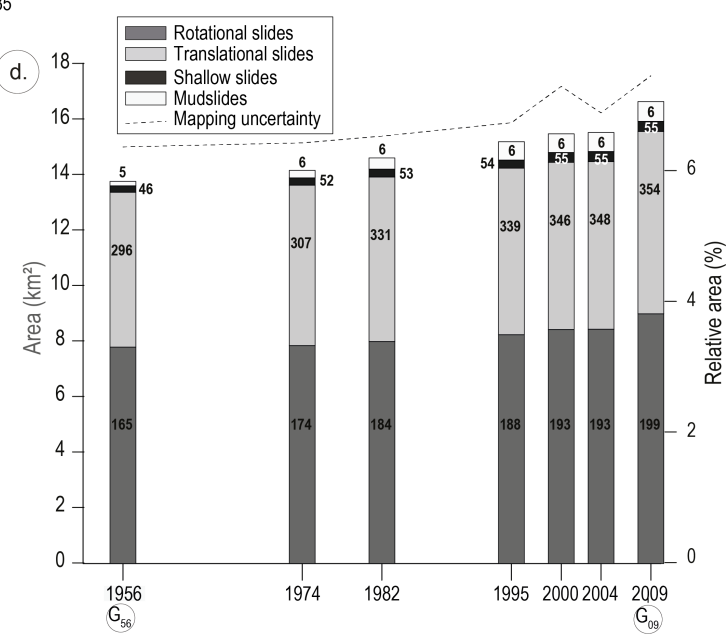

Figure 8. Statistics of the landslides observed in the Ubaye valley according to (a) the distribution of slope aspects; (b) the landslide degree of activity (relict, dormant and active), (c) the landslide distribution in terms of number and area, and (d) the area affected by different landslide types from 1956 to 2009 . The number of landslide per type is indicated on the graph. Dotted line represents the total area affected by landslide considering the quantitative mapping uncertainty.
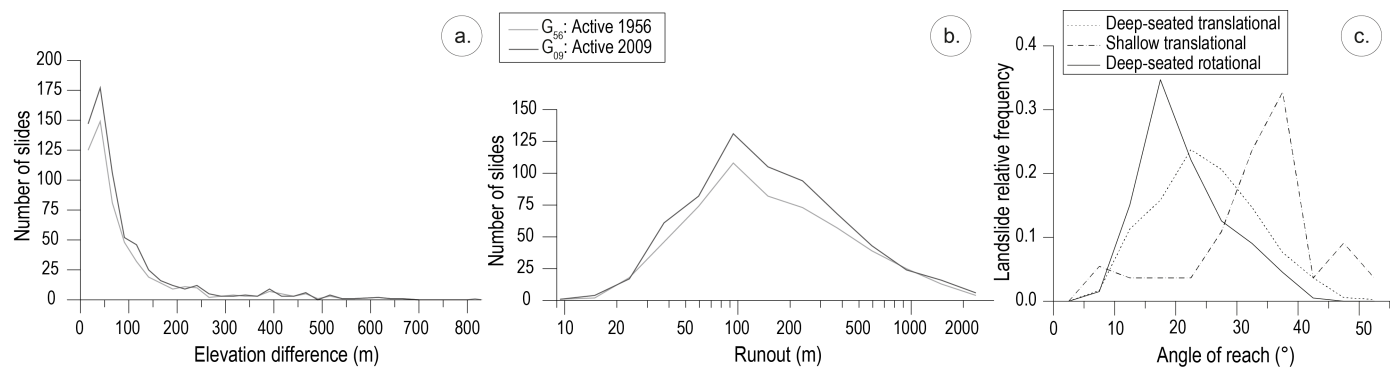

Figure 9. Analysis of the landslide geomorphological parameters: (a) Elevation difference and (b) runout distance of the new and (re)activated landslides observed in 1956 and 2009. (c) Angle of reach for the different landslide types in 2009.

landslides; Fig. 8b) cover an area of around $16.6 \pm 0.9 \mathrm{~km}^{2}$ in 2009 (Fig. 8d). According to the uncertainty index, the uncertain active landslides cover almost $1 \mathrm{~km}^{2}$ of the territory in $G_{09}$. The active landslides range in size from 100 to $140000 \mathrm{~m}^{2}$; the average size of the active landslides is equal to $28500 \mathrm{~m}^{2}$ (Fig. 8c). Among the active landslides, the rotational slides are more represented in surface than in number, meaning that they are, on average, larger than the shallow and deep translational landslides (Fig. 8d). Total of landslide areas with their mapping uncertainty (i.e. buffer zones) represented $16.6 \pm 0.5 \mathrm{~km}^{2}$ of the territory in $G_{09}$. Around 6 and $4 \%$ of the landslides reactivated in 1974 and 1982, respectively, might correspond to an uncertainty of mapping. This quantitative mapping uncertainty is higher in the 2000 inventory due to the geometrical correction of the corresponding orthophotograph (dotted line in Fig. 8c).

The sizes of the active landslides in 2009 and $1956\left(G_{09}\right.$; $G_{56}$; Table 3) are compared. From 1956 to 2009, 102 new landslides are observed corresponding to a surface increase of $2.9 \mathrm{~km}^{2}$ (1.3\% of the area). The analysis of the elevation differences (Table 2) for the landslides boundaries mapped in $G_{56}$ comparing to the ones mapped in $G_{09}$ indicates small differences, in the range between 20 and $100 \mathrm{~m}$, with an average of ca. $50 \mathrm{~m}$ (Fig. 9a). The runout distance ranges between 10 and more than $2000 \mathrm{~m}$ but most of the values range between 50 and $200 \mathrm{~m}$ (Fig. 9b). Figure 9c indicates that the 


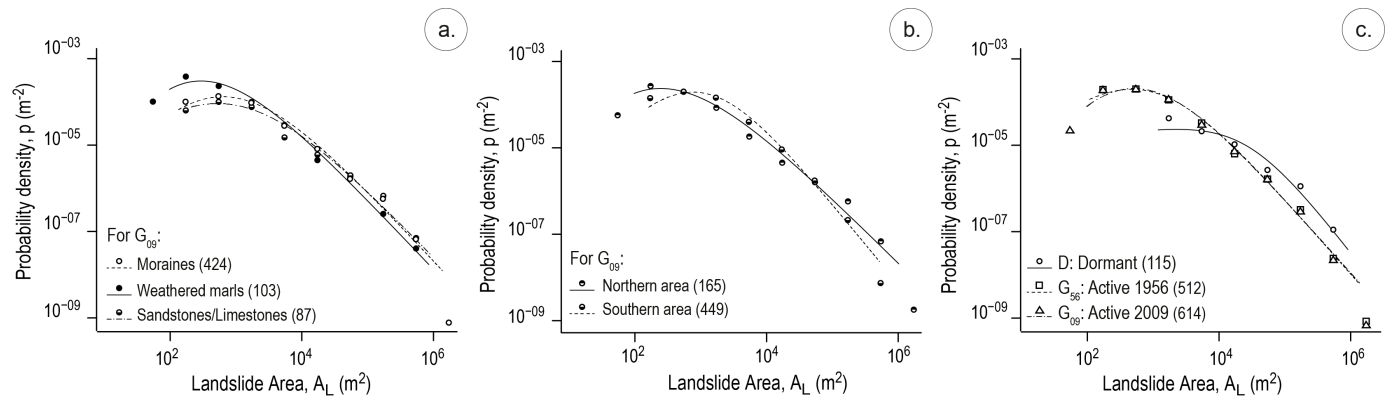

Figure 10. Landslide frequency-area distributions and maximum-likelihood fit of a Double-Pareto Simplified model. (a) Frequency-area distributions for three categories of lithology of the landslide bodies. (b) Frequency-area distributions for two morphological units of the Ubaye valley (right and left riverbanks of the Ubaye River corresponding, respectively, to the northern and southern areas). (c) Frequencyarea distributions for three categories of degrees of activity.

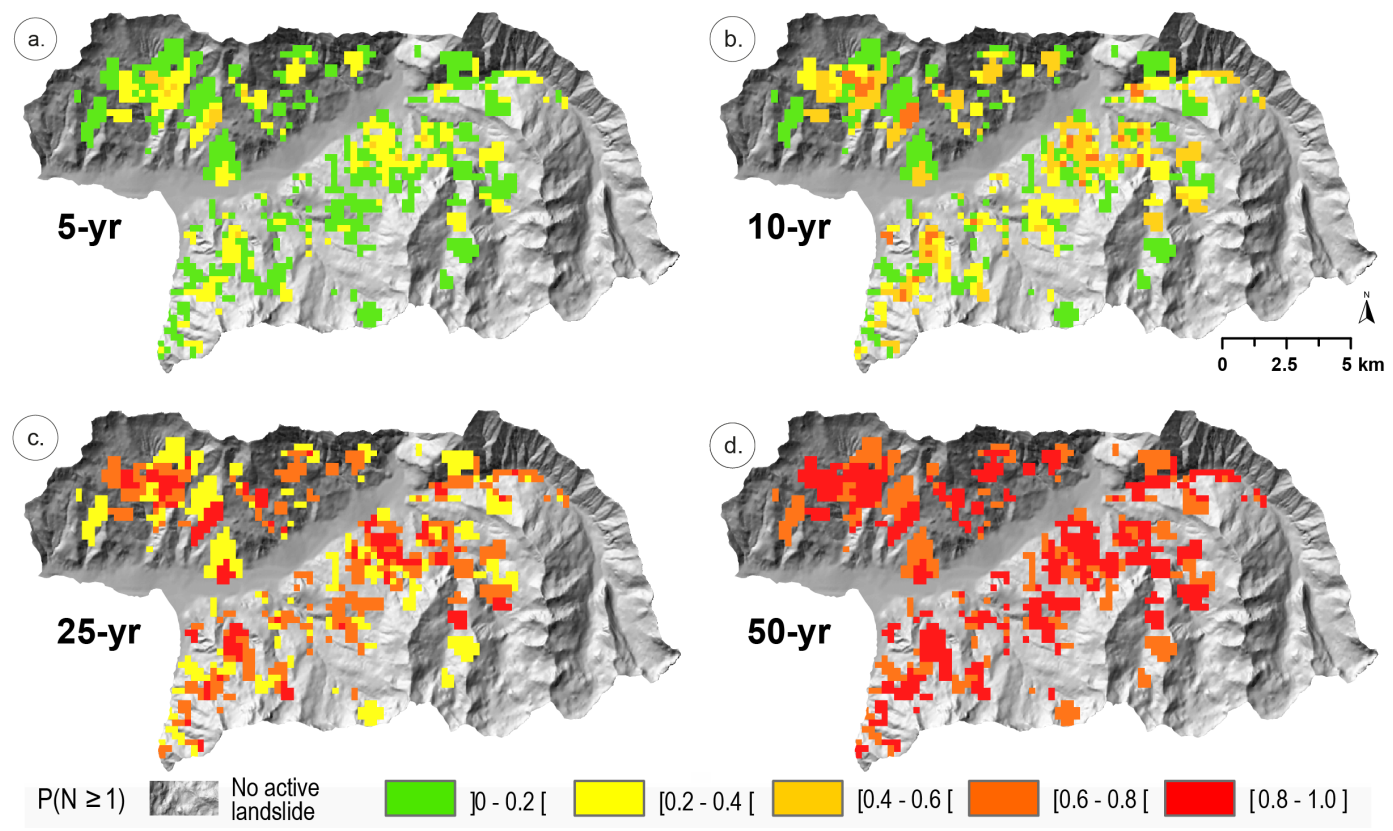

Figure 11. Exceedance probability of temporal occurrence of landslide (re)-activation calculated from the mean recurrence interval of past landslides (Fig. 6a) with a Poisson probability model. Exceedance probability is calculated for four return periods (5, 10, 25 and 50 years). A probability of zero is obtained in the areas where no active landslides are observed.

angles of reach are in the range $15-25^{\circ}$ for the rotational slides, in the range $12-35^{\circ}$ (with a scattered distribution) for the deep translational slides and in the range $30-40^{\circ}$ for the shallow translational slides. These values are consistent with the geomorphological features associated to these landslide types.

\subsection{Analysis of size-frequency distribution}

The multi-date landslide inventory was prepared with heterogeneous multi-source data at different spatial resolutions and scales. The landslide inventories are compared with the assumption that the heterogeneity of the data set and the interpretation rules used for mapping the landslide do not im- pact the landslide frequency-area distribution. Frequencyarea density functions were calculated by taking into account different landslides subsets (Fig. 10): (i) the geomorphological inventory of $2009\left(G_{09}\right.$; Table 3$)$ classified according to the lithology and, (ii) the geomorphological inventory of 2009 ( $G_{09}$; Table 3 ) classified according to the morphology; and (iii) the multi-date inventory classified according to landslide activity ( $D, G_{56}$ and $G_{09}$; Table 3 ).

The frequency-area distributions indicate the presence of few small landslides, meaning that some of the landslides are missing in the database because of their size. The frequency density for medium and large landslides follows a negative power law trend. The $\alpha$ values are $0.62 \pm 0.04$ (for weathered marls) and $0.57 \pm 0.01$ (for limestones, sand- 
stones and screes; Fig. 10a), meaning that large events can occur in both lithologies but are expected to be smaller in the weathered marls. The $\alpha$ values are different for the northern area $(0.51 \pm 0.03)$ than for the southern area $(0.86 \pm 0.03$; Fig. 10b). It indicates that the landslides are larger in the northern area explained by specific geomorphological conditions (higher number of steep slopes, presence of the thrust sheets). However, the frequency-area distribution is dependent on the number of events, and three very large landslides (Pra Bellon, Les Aiguettes and La Valette) are observed in this unit, biasing the calculation. In the southern area, the $\beta$ values are higher according to the frequency of the small landslides but the distribution is scattered with high values of standard deviation up to \pm 0.73 . Finally, the frequency-area distribution of the dormant landslides shows a completely different distribution without a rollover with respect to the active landslide because of their large size (Fig. 10c). The high variation of $\beta$ values ( $1.17 \pm 0.12$ to $4.49 \pm 0.73)$ can be related to the difficulty to map small events, especially in the past years, and thus their underestimation (Guzzetti et al., 2002). Despite these limitations, a rollover is observed for the smallest landslides, which are more frequent around $480 \mathrm{~m}^{2}$ in $1956\left(G_{56}\right)$ and around $520 \mathrm{~m}^{2}$ in $2009\left(G_{09}\right)$.

\subsection{Analysis of landslide temporal probability}

Knowing the recurrence time between successive failures for the period 1956-2009, the exceedance probability of landslide reactivation is estimated for four return periods from 5 to 50 years (Fig. 11). For a return period of 10 years, high probability of landslide reactivation is expected to the NW of the area, in relation to the numerous reactivations of the Pra Bellon, Les Aiguettes and La Valette landslides over the last 60 years. Table 5 indicates the number, area and percentage of cells for different temporal probabilities and return periods. Five probability classes are considered to highlight the evolution of landslide reactivation over time. Within 10 years, the probability that territory already affected by landslides is going to be reactivated is low for $66 \%$ of the whole area, while it was of $97 \%$ after 5 years (Table 5). Only $3 \%$ of the whole catchment has a high probability of activity considering a return period of 10 years (e.g. La Valette, Les Aiguettes and Pra Bellon landslides). Within 25 years, $30 \%$ of the territory has a probability higher than 0.8 to be reactivated, while in the next 50 years, it reaches almost $60 \%$. The computation is based on the temporal sequence analysed and therefore, less reliable for a return period of 50 years as it is close to the period considered in this study.

\section{Discussion: evolution of landslide activity}

This section discusses the evolution of landslide activity comparing inventories of different sources and temporal coverage: (i) the activity estimated from the multi-date inventory (Fig. 12), (ii) the punctual catalogue of events over the period

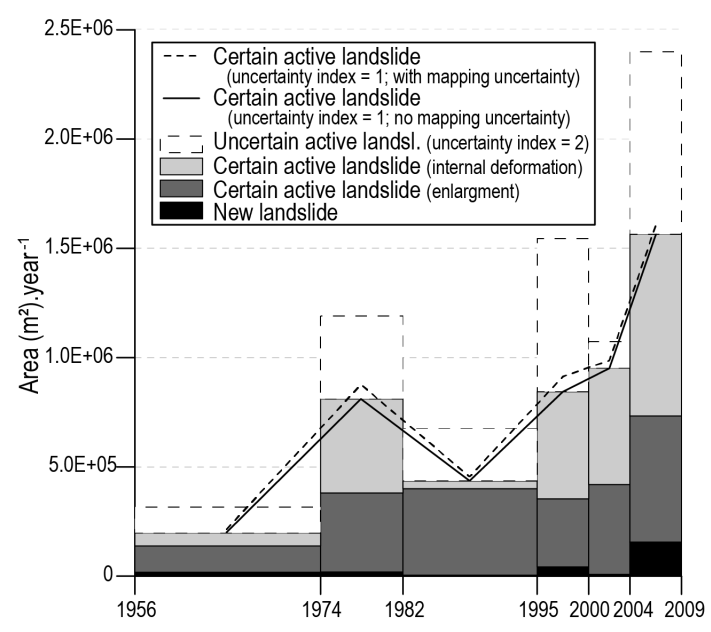

Figure 12. Areal extension of new and reactivated landslides per year. The dotted boxes indicate supposed active landslides according to the landslide interpretation uncertainty index (i.e. equal to 2) added in the attribute table and the dotted trend compares the total areas with buffers according to the qualitative uncertainty.

from 1850 to 2010 (Fig. 13) and (iii) all the inventories combined together for the common period (Fig. 14).

The analysis of landslide activity shows that $1.3 \%$ of the territory was affected by new landslides between 1956 and 2009 (Table 3). Deep-seated rotational landslides mainly affect the slopes in area, while translational landslides are more numerous in number. Table 4 indicates the evolution of landslide activity over the period 1956-2009 considering the number, area and density properties of the new and the reactivated landslides. On the whole territory, only a few new landslides (from 1.0 to 4.4 landslides $\mathrm{yr}^{-1}$ ) occurred, while landslide reactivations are numerous (from 7.3 to 33.1 landslides $\left.\mathrm{yr}^{-1}\right)$. The evolution of the active landslide area from 1956 to $2009\left(A_{2}, A_{3}, A_{4}, A_{5}, A_{6}\right.$ and $A_{7}$; Table 4) is presented in Fig. 12. For the entire period $\left(A_{2}-A_{7}\right)$, the new landslides are represented in black, the reactivated landslides defined by changes in size are in dark grey and the reactivated landslides defined by internal deformation are in grey; the uncertain active landslides (landslide interpretation uncertainty index equal to 2) are shown in dotted boxes. The certain active landslide areas including buffer zones corresponding to the resolution and land cover (represented by dotted lines in Fig. 12) indicate a higher uncertainty for the period 1995-2000. Visual analysis shows that areas affected by active landslides are similar between the periods 19741982 and 1995-2000 and then, they increase to 2009.

The periods of landslide activity covering the years 1850 2010 identified from dendrogeomorphological observations (Lopez-Saez et al., 2011, 2012, 2013; Fig. 13a-c) are compared to the landslide catalogue collected by the local risk managers (RTM and BRGM; Fig. 13d) since 1850. The dendrogeomorphological information was collected only at 
Table 5. Temporal probability of landslide reactivation for 5-, 10-, 25- and 50-year return periods. For each period the table indicates the number of cells, the landslide area in square kilometres and in percentage for five probability classes (see Fig. 11).

\begin{tabular}{|c|c|c|c|c|c|c|c|c|c|c|c|c|c|c|c|}
\hline \multicolumn{2}{|c|}{$P(N \geq 1)$} & \multicolumn{2}{|l|}{$0-0.2$} & \multicolumn{3}{|c|}{$0.2-0.4$} & \multicolumn{3}{|c|}{$0.4-0.6$} & \multicolumn{3}{|c|}{$0.6-0.8$} & \multicolumn{3}{|c|}{$0.8-1.0$} \\
\hline years & $\begin{array}{l}\# \\
\text { cells }\end{array}$ & $\begin{array}{l}\text { area } \\
\left(\mathrm{km}^{2}\right)\end{array}$ & $\%$ & \# cells & $\begin{array}{l}\text { area } \\
\left(\mathrm{km}^{2}\right)\end{array}$ & $\%$ & \# cells & $\begin{array}{l}\text { area } \\
\left(\mathrm{km}^{2}\right)\end{array}$ & $\%$ & $\begin{array}{l}\# \\
\text { cells }\end{array}$ & $\begin{array}{l}\text { area } \\
\left(\mathrm{km}^{2}\right)\end{array}$ & $\%$ & \# cells & $\begin{array}{l}\text { area } \\
\left(\mathrm{km}^{2}\right)\end{array}$ & $\%$ \\
\hline 5 & 540 & 33.8 & 65.7 & 261 & 16.3 & 31.8 & 21 & 1.3 & 2.6 & 0 & 0 & 0 & 0 & 0 & 0 \\
\hline 10 & 334 & 20.9 & 40.6 & 206 & 12.9 & 25.1 & 235 & 14.7 & 28.6 & 47 & 2.9 & 5.7 & 0 & 0 & 0 \\
\hline 25 & 0 & 0 & 0 & 334 & 20.9 & 40.6 & 0 & 0 & 0 & 337 & 21.1 & 41.0 & 151 & 9.4 & 8.4 \\
\hline 50 & 0 & 0 & 0 & 0 & 0 & 0 & 0 & 0 & 0 & 334 & 20.9 & 40.6 & 488 & 30.5 & 9.4 \\
\hline
\end{tabular}

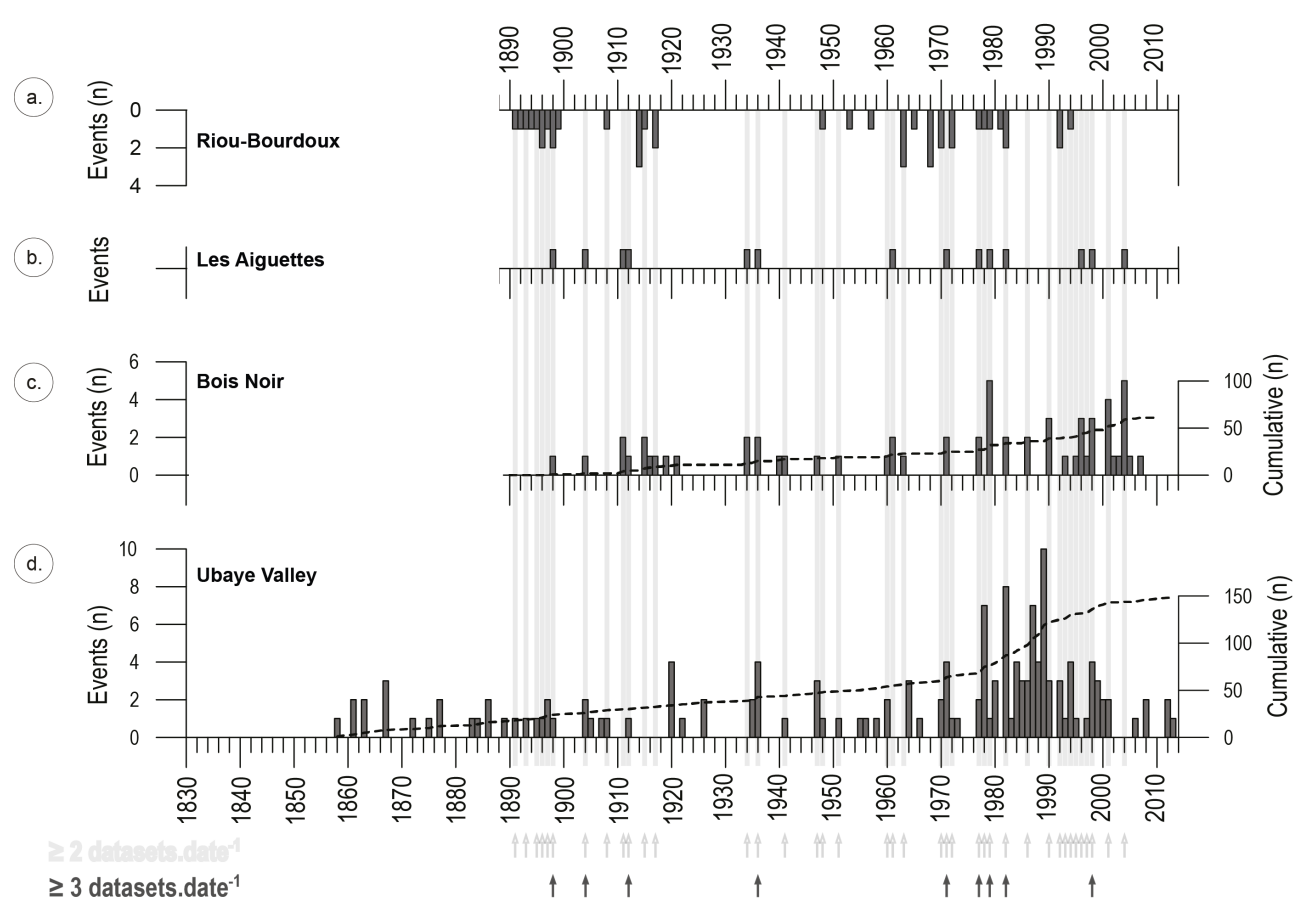

Figure 13. Comparative analysis of periods of landslide activity recorded in several data sets. (a) Landslide dendrogeomorphological observations for the Riou Bourdoux catchment (Lopez-Saez et al., 2013); (b) Dendrogeomorphological observations for the Pra Bellon landslide (Lopez-Saez et al., 2012); (c) Dendrogeomorphological observations for the Les Aiguettes landslide (Lopez-Saez et al., 2011) and (d) RTM and BRGM landslide catalogues for the Ubaye valley. Below, arrows point out the most active years considering at least 2 or 3 of the data sets presented.

some unstable slopes (Aiguettes, Pra Bellon and Bois Noir landslides; Fig. 1e-f), while the event catalogue covers the whole study area. Periods (years) of landslide activity are identified from the comparison of the landslide catalogues. A total of 31 and 10 periods with increased landslide activity are, respectively, identified in two and three data sets (arrows in Fig. 13). From the dendrogeomorphological analysis, Lopez-Saez et al. (2013) identified 12 major reactivations for the Aiguettes landslide (i.e. in 1898, 1904, 1911, 1916, 1936, 1961, 1971, 1977, 1979, 1996, 1998, and 2004). Considering the timing of annual tree ring formation at Bois Noir, landsliding is likely to have occurred in 1874-1875, 1896-1897, 1946-1947, 1992-1993, and 2003-2004 (Lopez-Saez et al., 2011). According to Lopez-Saez et al. (2012), the Pra Bellon landslide had no relevant reactivation for the period 1980
1990, while the La Valette landslide has been triggered in 1982 and major failures were observed at Super-Sauze between 1978 and 1982 (Flageollet et al., 1999; Malet, 2003). Figure 13 indicates that many reactivations were recorded at the Bois Noir landslide for the year 2004, but only a few landslides are recorded elsewhere in the region. The period between 1992 and 2000 is considered as active with at least more than two large events recorded in dendrogeomorphological archives. However, it is extremely difficult to extrapolate local information from specific slopes of different landslide types to the entire valley.

Figure 14a points out that the period between 1974 and 1982 recorded more new and reactivated landslides than the other periods with, respectively, 33 and 4 events $\mathrm{yr}^{-1}$. In comparison, less than 2 new landslides or 


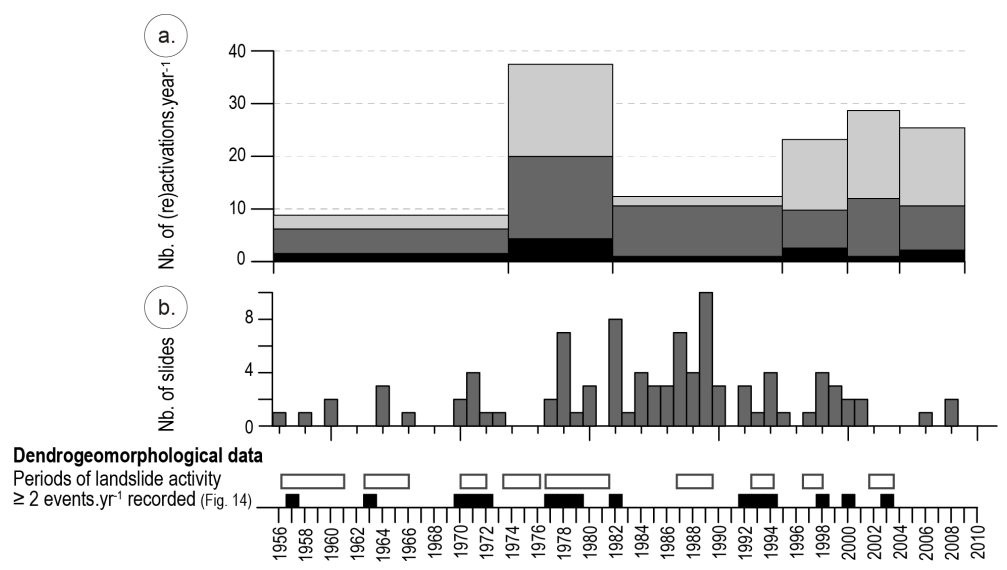

Figure 14. Comparison of landslide activity given by different landslide inventories available for the Ubaye valley. (a) Number of new landslides or landslide (re)-activations from the multi-date inventory. (b) Number of landslides from the historical landslide catalogue of RTM/BRGM and below, periods of landslide activity recorded by dendrogeomophological observations of two sites in the valley (Thiery, 2007).

12 reactivations $\mathrm{yr}^{-1}$ have been recorded in the first and third periods (1956-1974 and 1982-1995). After 1995, more landslides were registered. A peak of landslide activity (Fig. 13d) is observed in terms of number of events in 1989, but this is not observed considering the multi-date inventory and the evolution of landslide sizes and areas (Figs. 12 and 14a). For the period 1995-2009, the number of active landslides is roughly the same, while an increase of areas affected by landslides from 2004 to 2009 is recorded. Comparison with dendrogeomorphological archives are not steady-state however some periods of activity can be correlated over the whole data set of results, such as between 1956-1960, 19641966, 1970-1972, 1977-1980, 1982, 1987-1989, 19931994, 2000 and 2002-2003. For the most recent years, the catalogue of events recorded by the policy makers seems incomplete and dendrogeomorphological observations are missing (Fig. 14b).

\section{Conclusion}

The interpretation of aerial photographs and SAR images allowed us to increase the number of detected landslide events (new landslide or landslide reactivations) than those indicated in historical catalogues, and to prepare a multi-date inventory. However, the interpretation is difficult and depends on: (i) the skill of the geoscientist, (ii) the knowledge of the field conditions and (iii) the data considered to recognize landslide features. The empirical results given by the multidate inventory statistical analysis are interpreted considering the inventory completeness and reliability due to limitations and biases. A qualitative landslide interpretation index is proposed in addition to a mapping uncertainty measurement taking into account the data properties and the land cover affecting each landslide. The computed buffer areas showed that at least $85 \%$ of the landslides evolving with a size enlargement over time are not comprised into the mapping uncertainty (except considering the 2000 period with at least $60 \%$ of the landslides). A few enlargements of landslides (e.g. 6 and $4 \%$ of the landslides reactivated in 1974 and 1982, respectively) are either due to the uncertainty of mapping in forested area and/or influence of data quality, or correspond to a real reactivation in size. In addition, in optimal conditions (landslides with less than $50 \%$ under vegetal cover), we assume that our data set allows us to detect most of the landslides having a displacement larger than a distance of twice the data resolution. For instance, between 2004 and 2009, the displacement rate of the active landslide should be at least $0.2 \mathrm{~m} \mathrm{yr}^{-1}$ to be certainly detected following the approach described in this study.

Differences in area-frequency distributions are observed according to the geomorphological settings of the landslides and their degree of activity. It also reveals the difficulty to map the small size events. We assume that the inventory is complete for landslides with areas over $500 \mathrm{~m}^{2}$ (rollover of 480 and $520 \mathrm{~m}^{2}$ for $G_{56}$ and $G_{09}$, respectively) even if welltrained eyes are able to recognize landslides with areas of at least $100 \mathrm{~m}^{2}$.

L-band D-InSAR allowed the detection of slow-moving landslides on a portion of the territory (around $60 \%$ ) according to the SAR properties. It provided additional information on the active landslides (sometimes unknown or under forest) for the period 2007-2010 and allowed us to integrate new events in the last geomorphological inventory.

As multi-temporal inventories are time-consuming to prepare, only few works have been published on the temporal probability of occurrence of future landslides (Coe et al., 2000; Guzzetti et al., 2005; Lopez-Saez et al., 2012). The approach presented in this paper allows determination of quantitative probabilities of reactivation estimated directly from the frequency of past events combining recent very 
slow-moving landslides by SAR results interpretation and landslide (re)activations over the last 60 years by orthophotographs interpretation. The approach uses a Poisson probability model based on some assumptions even if most hazardous events, and especially landslides, are probably not independent and do not occur randomly (Coe et al., 2000). Indeed, a landslide reactivation can increase or decrease the slope susceptibility to future landslides, thus creating a lowto-high instability in the future. Changes in land use or climatic conditions also affect the future occurrence of landslides.

In addition, the preparation of a multi-date inventory as explained in this study induces underestimation of small events due to the limitations in the visual analysis because of the terrain conditions and the data sources. However, the vegetation indicator is useful to record reactivations when the precise landslide boundaries are not visible due to the forest coverage. The comparison of landslide activity measured by the multi-date inventory and by the landslide historical catalogue pointed out the incompleteness of the historical catalogue for the recent years. Even if they are definitively more complicated to interpret, construction of large multi-source data sets for multi-date inventory preparation is required for the analysis of landslide occurrences. Preliminary statistical analyses of landslide inventories are relevant to explore the spatial and temporal distribution of landslides events and assess the landslide hazard for different landslide types.

Acknowledgements. This work was supported by the Marie Curie Research and Initial Training Network "CHANGES: Changing Hydro-meteorological Risks as Analyzed by a New Generation of European Scientists", funded by the European Community's 7th Framework Programme FP7/2007-2013 under Grant Agreement No. 263953. The orthophotographs and elevation data were provided by IGN (Institut Géographique National) and other public partners. The access to ALOS/PALSAR images was given by the Japan Aerospace eXploration Agency (JAXA) and the European Space Agency (ESA) under the contract C1P.8859. The historical catalogue of landslide events was provided by the RTM-04 (Restauration des Terrains en Montagne) service of Département des Alpes-de-Haute-Provence. The authors would like to thank M. Rossi and M. Santangelo (CNR-IRPI, Italy) for their advices.

Edited by: T. Glade

Reviewed by: two anonymous referees

\section{References}

Ardizzone, F., Cardinali, M., Carrara, A., Guzzetti, F., and Reichenbach, P.: Impact of mapping errors on the reliability of landslide hazard maps, Nat. Hazards Earth Syst. Sci., 2, 3-14, doi:10.5194/nhess-2-3-2002, 2002.

Ardizzone, F., Cardinali, M., Galli, M., Guzzetti, F., and Reichenbach, P.: Identification and mapping of recent rainfall-induced landslides using elevation data collected by airborne Lidar, Nat.
Hazards Earth Syst. Sci., 7, 637-650, doi:10.5194/nhess-7-6372007, 2007.

Baynes, F. J., Lee, I. K., and Stewart, I. E.: A study of the accuracy and precision of some landslide risk analyses, Aust. Geomech., 37, 149-156, 2002.

Bell, R., Petschko, H., Röhrs, M., and Dix, A.: Assessment of landslide age, landslide persistence and human impact using airborne laser scanning digital terrain models, Geogr. Anna. A, 94, 135156, 2012.

Brardinoni, F., Slaymaker, O., and Hassan, M. A.: Landslide inventory in a rugged forested watershed: a comparison between air-photo and field survey data, Geomorphology, 54, 179-196, 2003.

Campbell, R. H.: Isopleth map of landslide deposits, Point Dume quadrangle, Los Angeles County, California, an experiment in generalizing and quantifying areal distribution of landslides: U.S. Geological Survey Miscellaneous Field Studies Map MF-535, scale $1: 24000,1973$.

Canuti, P., Casagli, N., Ermini, L., Fanti, R. and Farina, P.: Landslide activity as a geoindicator in Italy: significance and new perspectives from remote sensing, Environ. Geol., 45, 907-919, 2004.

Carrara, A., Cardinali, M., and Guzzetti, F.: Uncertainty in assessing landslide hazard and risk, ITC J., 2, 172-183, 1992.

Cascini, L., Fornaro, G., and Peduto, D.: Analysis at medium scale of low-resolution DInSAR data in slow-moving landslideaffected areas, ISPRS J. Photogramm., 64, 598-611, 2009.

Coe, J. A., Michael, J. A., Crovelli, R. A., and Savage, W. Z.: Preliminary map showing landslide densities, mean recurrence intervals, and exceedance probabilities as determined from historic records, Seattle, Washington, USA. USGS Open-File Report 000303, 2000.

Colesanti, C. and Wasowski, J.: Investigating landslides with spaceborne Synthetic Aperture Radar (SAR) interferometry, Eng. Geol., 88, 173-199, 2006.

Corominas, J.: The angle of reach as a mobility index for small and large landslides, Can. Geotech. J., 33, 260-271, 1996.

Corominas, J., van Westen, C. J., Frattini, P., Cascini, L., Malet, J.-P., Fotopoulou, S., Catani, F., Eeckhaut, M., Mavrouli, O., Agliardi, F., Pitilakis, K., Winter, M. G., Pastor, M., Ferlisi, S., Tofani, V., Hervás, J., and Smith, J. T.: Recommendations for the quantitative analysis of landslide risk, B. Eng. Geol. Environ., 73, 209-263, 2014.

Crovelli, R. A.: Probability models for estimation of number and costs of landslides. U.S. Geological Survey Open File Report 00249, 2000.

Cruden, D. M. and Varnes, D. J.: Landslide types and processes, in: Landslides-investigations and mitigation, edited by: Turner, R. L. and Schuster, A. K., 36-75, Washington D.C., USA, 1996.

DeGraff, J. V and Canuti, P.: Using isopleth mapping to evaluate landslide activity in relation to agricultural practices, Bull. Int. Assoc. Eng. Geol., 38, 61-71, 1988.

Doin, M.-P., Lodge, F., Guillaso, S., Jolivet, R., Lasserre, C., Ducret, G., Grandin, R., Pathier, E., and Pinel, V.: Presentation of the small baseline processing chain on a case example: the Etna deformation monitoring from 2003 to 2010 using ENVISAT data, in Proc. "Fringe 2011 Workshop", Frascati, Italy, 19-23 September 2011, p. 7., 2011. 
Flageollet, J.-C., Maquaire, O., Martin, B., and Weber, D.: Landslides and climatic conditions in the Barcelonnette and Vars basins (Southern French Alps, France), Geomorphology, 30, 6578, 1999.

Florsheim, J. L. and Nichols, A.: Landslide area probability density function statistics to assess historical landslide magnitude and frequency in coastal California, Catena, 109, 129-138, 2013.

Galli, M., Ardizzone, F., Cardinali, M., Guzzetti, F. and Reichenbach, P.: Comparing landslide inventory maps, Geomorphology, 94, 268-289, 2008.

Günther, A., Reichenbach, P., Malet, J.-P., Eeckhaut, M., Hervás, J., Dashwood, C., and Guzzetti, F.: Tier-based approaches for landslide susceptibility assessment in Europe, Landslides, 10, 529546, 2013.

Guzzetti, F., Cardinali, M., and Reichenbach, P.: Map of sites historically affected by landslides and floods, The AVI Project, CNR Gruppo Nazionale per la Difesa dalle Catastrofi Idrogeologiche Publication number 1356, scale 1:1200 000, 1996.

Guzzetti, F., Cardinali, M., Reichenbach, P., and Carrara, A.: Comparing landslide maps: a case study in the upper Tiber River Basin, Central Italy, Environ. Manage., 25, 247-363, 2000.

Guzzetti, F., Malamud, B. D., Turcotte, D. L., and Reichenbach, P.: Power-law correlations of landslide areas in central Italy, Earth Planet. Sc. Lett., 195, 169-183, 2002.

Guzzetti, F., Reichenbach, P., Cardinali, M., Ardizzone, F., and Galli, M.: The impact of landslides in the Umbria region, central Italy, Nat. Hazards Earth Syst. Sci., 3, 469-486, doi:10.5194/nhess-3-469-2003, 2003.

Guzzetti, F., Reichenbach, P., Cardinali, M., Galli, M., and Ardizzone, F.: Probabilistic landslide hazard assessment at the basin scale, Geomorphology, 72, 272-299, 2005.

Guzzetti, F., Galli, M., Reichenbach, P., Ardizzone, F., and Cardinali, M.: Landslide hazard assessment in the Collazzone area, Umbria, Central Italy, Nat. Hazards Earth Syst. Sci., 6, 115-131, doi:10.5194/nhess-6-115-2006, 2006.

Guzzetti, F., Mondini, A. C., Cardinali, M., Fiorucci, F., Santangelo, M., and Chang, K.-T.: Landslide inventory maps: new tools for an old problem, Earth-Science Rev., 112, 42-66, 2012.

Haneberg, W. C., Cole, W. F., and Kasali, G.: High-resolution lidarbased landslide hazard mapping and modeling, UCSF Parnassus Campus, San Francisco, USA, B. Eng. Geol. Environ., 68, $263-$ 276, 2009.

Hanssen, R. F.: Radar interferometry: data interpretation and error analysis, Kluwer, Academic Publishers, Dordrecht, the Netherlands, 308 pp., 2001.

Jorda, M.: Morphogenèse et évolution des paysages des Alpes de Haute-Provence depuis le Tardiglaciaire. Facteurs naturels et facteurs anthropiques, Bull. de l'Association des Géographes Français, 472, 295-304, 1980.

Lopez-Saez, J., Corona, C., Stöffel, M., Astrade, L., Berger, F., and Malet, J.-P.: Dendrogeomorphic reconstruction of past landslide reactivation with seasonal precision: the Bois Noir landslide, southeast French Alps, Landslides, 9, 189-203, 2011.

Lopez-Saez, J., Corona, C., Stöffel, M., Schoeneich, P., and Berger, F.: Probability maps of landslide reactivation derived from treering records: Pra Bellon landslide, Southern French Alps, Geomorphology, 138, 189-202, 2012.

Lopez-Saez, J., Corona, C., Stöffel, M., and Berger, F.: Highresolution fingerprints of past landsliding and spatially explicit, probabilistic assessment of future reactivations: Aiguettes landslide, southeastern French Alps, Tectonophysics, 602, 355-369, 2013.

Lu, P., Casagli, N., Catani, F., and Tofani, V.: Persistent Scatterers Interferometry Hotspot and Cluster Analysis (PSI-HCA) for detection of extremely slow-moving landslides, Int. J. Remote Sens., 33, 466-489, 2012.

Malamud, B. D., Turcotte, D. L., Guzzetti, F., and Reichenbach, P.: Landslide inventories and their statistical properties, Earth Surf. Processes, 29, 687-711, 2004.

Malet, J.-P.: Les “glissements de type écoulement" dans les marnes noires des Alpes du Sud. Morphologie, fonctionnement et modeìlisation hydro-meìcanique, $\mathrm{PhD}$ Thesis, University Louis Pasteur, Strasbourg, France, 2003.

Malet, J.-P., van Asch, T. W. J., van Beek, R., and Maquaire, O.: Forecasting the behaviour of complex landslides with a spatially distributed hydrological model, Nat. Hazards Earth Syst. Sci., 5, 71-85, doi:10.5194/nhess-5-71-2005, 2005a.

Malet, J.-P., Laigle, D., Remaître, A., and Maquaire, O.: Triggering conditions and mobility of debris flows associated to complex earthflows, Geomorphology, 66, 215-235, 2005b.

Marchesini, I., Santangelo, M., Fiorucci, F., Cardinali, M., Rossi, M., and Guzzetti, F.: A GIS method for obtaining geologic bedding attitude, in: Landslide Science and Practice, edited by: Margottini, C., Canuti, P., and Sassa, K., Springer, Berlin, Heidelberg, Germany, 243-247, 2013.

Martha, T. R., Kerle, N., Jetten, V., van Westen, C. J., and Kumar, K. $\mathrm{V}$. : Characterising spectral, spatial and morphometric properties of landslides for semi-automatic detection using object-oriented methods, Geomorphology, 116, 24-36, 2010.

Maquaire, O., Malet, J.-P., Remaître, A., Locat, J., Klotz, S., and Guillon, J.: Instability conditions of marly hillslopes: towards landsliding or gullying? The case of the Barcelonnette Basin, South East France, Eng. Geol., 70, 109-130, 2003.

McCalpin, J.: Preliminary age classification of landslides for inventory mapping, Proc. Annu. Symp. Eng. Geol. Soil Eng., 21, 99 111, 1984.

Metternicht, G., Hurni, L., and Gogu, R.: Remote sensing of landslides: an analysis of the potential contribution to geo-spatial systems for hazard assessment in mountainous environments, Remote Sens. Environ., 98, 284-303, 2005.

Razak, K. A., Straatsma, M. W., van Westen, C. J., Malet, J.-P., and de Jong, S. M.: Airborne laser scanning of forested landslides characterization: terrain model quality and visualization, Geomorphology, 126, 186-200, 2011.

Razak, K. A., Santangelo, M., van Westen, C. J., Straatsma, M. W., and de Jong, S. M.: Generating an optimal DTM from airborne laser scanning data for landslide mapping in a tropical forest environment, Geomorphology, 190, 112-125, 2013.

Reichenbach, P., Guzzetti, F., and Cardinali, M.: Map of sites historically affected by landslides and floods in Italy, 2nd edition, CNR GNDCI publication n. 1786, Rome, Italy, scale 1:1200000, 1998.

Remaître, A., Malet, J., Maquaire, O., Ancey, C., and Locat, J.: Flow behaviour and runout modelling of a complex debris flow in a clay-shale basin, Earth Sci. Rev., 30, 479-488, 2005.

Rosen, P. A., Hensley, S., Peltzer, G., and Simons, M.: Updated repeat orbit interferometry package released, Eos, Trans. Am. Geophys. Union, 85, 47-47, 2004. 
Rossi, M., Ardizzone, F., Cardinali, M., Fiorucci, F., Marchesini, I., Mondini, A. C., Santangelo, M., Ghosh, S., Riguer, D. E. L., Lahousse, T., Chang, K. T., and Guzzetti, F.: A tool for the estimation of the distribution of landslide area in R, Geophys. Res. Abstr., 14, EGU2012-9438-1, 2012.

Salomé, A. I. and Beukenkamp, P.: Geomorphological mapping of a high-mountain area in black and white, Z. Geomorphol., 33, 19-23, 1989.

Salvati, P., Guzzetti, F., Reichenbach, P., Cardinali, M., and Stark, C. P.: Map of landslides and floods with human consequences in Italy. CNR GNDCI publication n. 2822, Rome, Italy, scale $1: 1200000,2003$.

Santangelo, M., Marchesini, I., Bucci, F., Cardinali, M., Fiorucci, F., and Guzzetti, F.: An approach to reduce mapping errors in the production of landslide inventory maps, Nat. Hazards Earth Syst. Sci., 15, 2111-2126, doi:10.5194/nhess-15-2111-2015, 2015.

Schlögel, R., Torgoev, I., De Marneffe, C., and Havenith, H.-B.: Evidence of a changing size-frequency distribution of landslides in the Kyrgyz Tien Shan, Central Asia, Earth Surf. Processes, 36, 1658-1669, 2011.

Schlögel, R., Doubre, C., Malet, J.-P., and Masson, F.: Landslide deformation monitoring with ALOS/PALSAR imagery: a DInSAR geomorphological interpretation method, Geomorphology, 231, 314-330, 2015.

Shannon, C. E.: Communication in the presence of noise, P. I.R.E., 37, 10-21, 1949.

Singhroy, V. and Molch, K.: Characterizing and monitoring rockslides from SAR techniques, Adv. Space. Res., 33, 290-295, 2004

Stark, C. P. and Hovius, N.: The characterization of landslide size distributions, Geophys. Res. Lett., 28, 1091-1094, 2001.

Stien, D.: Glissements de terrains et enjeux dans la vallée de l'Ubaye et le pays de Seyne. Rapport ONF-RTM, Division de Barcelonnette, France, 2001.

Thiery, Y.: Susceptibilité du Bassin de Barcelonnette (Alpes du sud, France) aux mouvements de versant?: cartographie morphodynamique, analyse spatiale et modélisation probabiliste, Thèse de Doctorat, Université de Caen Basse-Normandie, France, 2007.

Thiery, Y., Malet, J.-P., Sterlacchini, S., Puissant, A., and Maquaire, O.: Landslide susceptibility assessment by bivariate methods at large scales: application to a complex mountainous environment, Geomorphology, 92, 38-59, 2007.
Thiery, Y., Maquaire, O., and Fressard, M.: Application of expert rules in indirect approaches for landslide susceptibility assessment, Landslides, 11, 411-424, 2014.

Travelletti, J., Malet, J.-P., and Delacourt, C.: Image-based correlation of Laser Scanning point cloud time series for landslide monitoring, Int. J. Appl. Earth Obs., 32, 1-18, 2014.

van den Eeckhaut, M., Poesen, J., Verstraeten, G., Vanacker, V., Moeyersons, J., Nyssen, J., and van Beek, L. P. H.: The effectiveness of hillshade maps and expert knowledge in mapping old deep-seated landslides, Geomorphology, 67, 351-363, 2005.

van den Eeckhaut, M., Poesen, J., Govers, G., Verstraeten, G., and Demoulin, A.: Characteristics of the size distribution of recent and historical landslides in a populated hilly region, Earth Planet. Sc. Lett., 256, 588-603, 2007.

van den Eeckhaut, M., Hervás, J., Jaedicke, C., Malet, J.-P., Montanarella, L., and Nadim, F.: Statistical modelling of Europe-wide landslide susceptibility using limited landslide inventory data, Landslides, 9, 357-369, 2012.

Varnes, D. J.: Slope movement types and processes, in: Special Report 176: Landslides: Analysis and Control, edited by: Schuster, R. L. and Krizek, R. J., 11-33, Transportation and Road Research Board, National Academy of Science, Washington, D.C., USA, 1978.

Wills, C. J. and McCrink, T. P.: Comparing landslide inventories: the map depends on the method, Environ. Eng. Geosci., 8, 279293, 2002.

Wolfe, M. D. and Williams, J. W.: Rates of landsliding as impacted by timber management activities in Northwestern California, Discussion Bull. Of Assoc. Eng. Geol., 24, 429-431, 1987.

Wright, R. H., Campbell, R. H. and Nilsen, T. H.: Preparation and use of isopleth maps of landslide deposits, Geology, 483-486, 1974.

ZERMOS: Carte des Zones Exposées à des Risques liés aux MOuvements du Sol et du sous-sol, Barcelonnette, 1/25 000, 1975.

Zhao, C., Lu, Z., Zhang, Q. and de la Fuente, J.: Large-area landslide detection and monitoring with ALOS / PALSAR imagery data over Northern California and Southern Oregon, USA, Remote Sens. Environ., 124, 348-359, 2012. 